\title{
A Review of Juvenile Redclaw Crayfish Cherax quadricarinatus (von Martens, 1898) Aquaculture: Global Production Practices and Innovation
}

\author{
Damian P. Rigg, ${ }^{1}$ Jamie E. Seymour, ${ }^{1}$ Robert L. Courtney ${ }^{1}$ and Clive M. Jones ${ }^{1, *}$ \\ 'James Cook University, PO Box 6811, Cairns, Queensland 4870, Australia. \\ ${ }^{*}$ Corresponding Author._clive.jones@jcu.edu.au \\ E-mail:damian.rigg@jcu.edu.au; jamie.seymour@jcu.edu.au; and robert.courtney@jcu.edu.au.
}

\section{A B S T R A C T}

The Australian Redclaw crayfish, Cherax quadricarinatus, has been the subject of aquaculture development for more than 3 decades. Farm production from Australia and from around the world for this species has been relatively low, as suitable production technology continues to develop. The production of redclaw juveniles for the purpose of stocking to ponds for on-growing to marketable size, has been a particular constraint and new approaches to breeding and mass production of craylings have provided renewed impetus to industry expansion. This paper reviews the literature concerning redclaw juvenile production and provides a status report of current practices and innovations that may support further expansion of redclaw aquaculture.

Copyright (C) 2020 by The Author(s). Published by the International Association of Astacology. This article is distributed under the terms of the Creative Commons Attribution License (CC-BY 4.0), which permits unrestricted use, distribution, and reproduction in any medium, provided the original author and source are credited.

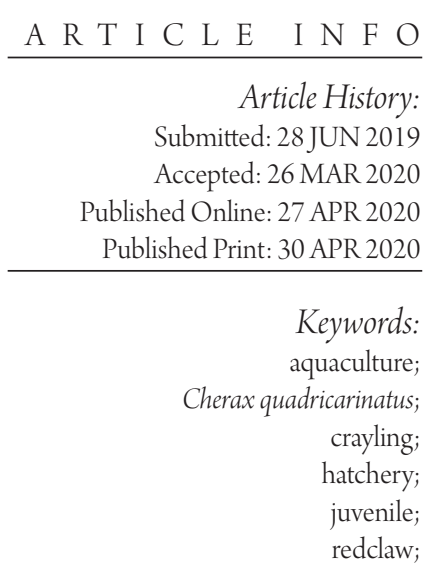

\section{INTRODUCTION}

The world wild-caught seafood catch has reached and may already have exceeded sustainable levels of production in many fisheries worldwide (Henriksson et al. 2012). Feeding a projected world population of 9 billion by 2050 will be a challenge faced in all food production (Msangi et al. 2013) and aquaculture will take an increasingly larger role in providing seafood protein. It is estimated that by 2030 aquaculture will provide half of all seafood production, possibly rising to an even greater proportion beyond that date (Msangi et al. 2013).

Aquaculture in Australia has also expanded to meet these demands, the major components of the aquaculture industry in Australia consisting of marine and freshwater finfish and crustaceans and a range of marine molluscs (Savage and Hobsbawn 2015). Within the freshwater aquaculture category are three freshwater crayfish groups. These groups are comprised of Cherax species and include yabbies (Cherax destructor Clark, Cherax albidus Clark), marron (Cherax cainii Austin, Cherax tenuimanus (Smith)) and redclaw (C. quadricarinatus (von Martens)). Of these species, redclaw is the only tropical species, and one that has been widely heralded as an excellent candidate for aquaculture.
Production of the juvenile stages of redclaw has been a significant constraint to commercial development. The following provides a review of the literature concerning juvenile redclaw aquaculture to collate existing knowledge and identify knowledge gaps that further research might resolve.

\section{REDCLAW BACKGROUND}

Redclaw is the common name of the freshwater crayfish Cherax quadricarinatus. This large and attractive crayfish is a native of westerly flowing rivers in far northwestern Queensland and the Northern Territory in Australia, as well as areas of southern Papua New Guinea (Jones 1990a, 1990b; Jones and Ruscoe 2002; Webster et al. 2004; Bugnot and López Greco 2009; Ghanawi and Saoud 2012; Saoud et al. 2013; Zhu et al. 2013; Stumpf et al. 2014). Well known to the communities of these remote areas, the species was first introduced to the broader public via its launch in the late 1980s in southeast Queensland as an exciting new 'sunrise' aquaculture species (Jones 1990a) and a potential revenue source for farmers.

Redclaw belongs to the family Parastacidae, which is only found in Australia, New Zealand, New Guinea, Madagascar and parts of 
South America (Ackefors 2000). The genus Cherax includes the Yabby (C. destructor, C. albidus) found in more southerly central and western regions of Australia, and the Marron ( $C$. cainii, $C$. tenuimanus), all of which have been assessed and developed for aquaculture. For redclaw, C. quadricarinatus, the specific name refers to the four keel-shaped ridges on the cephalothorax, and the common name is derived from the red coloration of a decalcified patch on the outer margin of the chelicerae of sexually mature males.

Aquaculture of redclaw, yabbies and marron in Australia began around the same time in the mid 1980s. The species have much in common biologically, but their specific aquaculture has developed independently. Yabbies are primarily cultured extensively in farm dams, while marron and redclaw are cultured semi-intensively in purpose-built, managed earthen ponds. Marron require temperate conditions for culture and are relatively slow growing, taking 2 or more years to achieve a minimum marketable size. They are advantaged however, by reaching $500 \mathrm{~g}$ or more (over several years), making them comparable to marine lobsters in the market place. Redclaw have an advantageous combination of attractive aquaculture characteristics, including fast growth under their preferred tropical conditions, reaching 100 to $200 \mathrm{~g}$ within 12 months of growth. Redclaw is a robust species that is relatively easy to culture, and its positive aquaculture credentials have resulted in widespread translocation around the world.

\section{REDCLAW REPRODUCTIVE BIOLOGY}

The process by which redclaw reproduce provides an advantage to aquaculture production due to its simplicity compared with other crustaceans (Medley et al. 1994), including shrimp, prawns and lobsters. The most significant attribute is the absence of free-living larval stages to manage in cultivation. After the male redclaw deposits a spermatophore, or sperm package on the sternum of the female, eggs are released and within 24-48 hours they are fertilized in a temporary brood chamber on the underside of the females curled abdomen, in a swirling current created by the beating of the pleopods (Jones 1990b). The fifth pair of pereiopods have sharp tips that are used to break open the sperm packet and the released sperm are then also drawn into the brood chamber, within which the fertilization takes place (Jones 1990b). Eggs then become attached to setae, or fine hairs, on the pleopods on the female's abdomen, and go through 10 developmental stages over the next 31 days before hatching (García-Guerrero et al. 2003a).

The developmental stages of redclaw from fertilized egg have been well described by García-Guerrero et al. (2003a). They term the first hatched stage as post-embryo 1 or stage 11 , at 32-36 days after spawning. At this time, all adult appendages are fully formed and present except for the uropods, and the abdomen is paddle-shaped (García-Guerrero et al. 2003a). The cephalothorax is larger than the abdomen due to the presence of a yolk sac, which indicates nil feeding activity, and there is no locomotion as the developing crayfish remains attached to the maternal pleopods (García-Guerrero et al. 2003a). Post-embryo 2 (stage 12, days 37-41) has the cephalothorax taking its final shape and nearly all the physical characteristics of the adult are now evident (García-Guerrero et al. 2003a), although there is still no feeding or locomotion as the crayfish remains attached to the female (García-Guerrero et al. 2003a). A significant change happens at day 42 when the yolk is depleted and the cephalothorax is of final proportion and shape and exogenous feeding begins. Now capable of independent locomotion, these are the earliest stage juveniles, otherwise referred to as post-larval stage 3 or craylings. These craylings progressively leave their mother for brief forays to seek shelter and food (García-Guerrero et al. 2003a), becoming fully independent within a week. After their next moult, they are referred to as juveniles until they mature.

\section{BENEFICIAL ATTRIBUTES OF REDCLAW FOR COMMERCIAL AQUACULTURE}

From the earliest investigations into the suitability of redclaw for commercial aquaculture in the early 1980s, through to the present day, redclaw has shown great potential to become a high value food fish (Jones 1989; 1990b). Redclaw are hardy and benefit from physical, biological and commercial properties which translate to a ready adaptability to farming in sub-tropical and tropical areas worldwide. This potentially broad geographic range, coupled with physical robusticity, straightforward life-cycle and production technology as well as a low protein food requirement, mean that they are economic to produce (FAO 2017). Redclaw also have a substantial return in terms of meat yield, returning a meat to body weight ratio of around $30 \%$, which compares advantageously with other commercially valuable crustaceans (Masser and Rouse 1997). Additionally, the flesh texture and flavour of redclaw compares favourably with those of marine species (Bitomsky 2008), and due to the resemblance to marine lobsters, redclaw are positioned at the premium end of the crustacean market (FAO 2017).

\section{BIOLOGICAL AND BEHAVIOURAL ATTRIBUTES}

Redclaw exhibit many excellent qualities which translate well to aquaculture, such as their hardiness in regard to surviving adverse conditions, low intraspecific aggression and low level of destructive burrowing behavior (Jones 1990a; Masser and Rouse 1997). The species can tolerate a wide range of temperatures from 16 to $32^{\circ} \mathrm{C}$ (King 1994; Thompson et al. 2004; García-Guerrero et al. 2013), however they grow best between 20 and $34^{\circ} \mathrm{C}$ (Jones $1990 \mathrm{~b})$ and will perish at temperatures below $10^{\circ}$ and greater than $36^{\circ} \mathrm{C}$ (FAO 2017). Capacity to tolerate low dissolved oxygen conditions, as low as 1ppm (Masser and Rouse 1997), is a further advantage. One of the most significant positive attributes is the lack of free-living larval stages, these being completed within the egg (Jones 1990b; FAO 2017), rather than as independent larvae requiring specific food and environmental conditions (Jones 1995b; Thompson et al. 2004; Thompson et al. 2006). Another attractive attribute of redclaw is their relatively fast growth rate, reaching marketable size of 60-200 g within 9 months (Thompson et al. 2004; FAO 2017).

Harvesting of aquacultured redclaw is most commonly performed using a flowtrap as described by Jones and Curtis (1994), that comprises a closed box with an attached ramp and a water flow down the ramp. The redclaw walk up the ramp against the water flow and into the 'flow trap' (Jones and Curtis 1994). 
Redclaw are positively rheotactic with a very strong response to water flow (Jones 1990a). In their natural habitat they inhabit permanent water in the upper reaches of streams and rivers, often in discrete water holes (referred to in Australia by their Indigenous name - billabong) that form during the dry season when rivers are not flowing. Their natural response to walk against the water flow enables them move towards the permanent water if they're swept downstream during the wet season (FAO 2017). This behaviour has been harnessed for aquaculture, providing an effective and efficient method of harvesting.

\section{REDCLAW AQUACULTURE IN AUSTRALIA}

At present redclaw are farmed commercially on 22 licensed farms in Queensland (Queensland Government 2020) stretching from the Atherton Tablelands in the far north, down to the Sunshine Coast and State border areas in the extreme south of Queensland. In the financial year 2018-2019, production decreased by $8.1 \%$ from $48.8 \mathrm{t}$ in $2017-2018$ to $44.9 \mathrm{t}$ and value decreased from $\mathrm{A} \$ 1.3 \mathrm{M}$ to $\mathrm{A} \$ 1.2 \mathrm{M}$ (Queensland Government 2020). The average price per kilogram also decreased from \$26.06 in 2017-2018 to \$25.69 in 2018-2019 (Queensland Government 2020). Over time, there have been large fluctuations in production (Figure 1) and the industry has failed to gather new momentum from a high of $105 \mathrm{t}$ reached in 2005-2006 (Queensland Government 2016).

The reasons for the fluctuations in both the production volume of redclaw produced in Queensland each year (Figure 1) and the price per tonne (Figure 2) are unclear. After production steadily increased over the period from 1995-1996 to 2006-2007, there was an equivalent decrease from 2006-2007 to 2014-2015, followed by an increase in 2016-2017 and a subsequent drop again in 2017-2018. Despite the production volume variability, the price per tonne (Figure 2) has generally trended upward. This may suggest that the price is decoupled from the production output and that price is not demand-driven. Other factors that could explain this redclaw production variation may be environmental factors such as rainfall, or the investment climate, with factors such as government subsidies and bank interest rates. Redclaw farmers have indicated the availability of seedstock (juvenile redclaw) as a constraint, with most farmers having to produce their own juveniles rather than purchase them from a seedstock supplier as per most other successful aquaculture industries.

\section{OTHER FAVOURABLE AQUACULTURE ATTRIBUTES}

Other favourable attributes of redclaw for commercial production in aquaculture include:

High fecundity, each adult female is able to produce three to five clutches of 300 to $800+$ eggs per summer breeding season, and potentially more if environmental breeding conditions are extended (Jones 1995b; Barki et al. 1997; Barki and Karplus 1999; Levi et al. 1999; Karplus et al. 2003; Bugnot and López Greco 2009; FAO 2017).

Disparate wild population strains have provided the basis for selective breeding for improved aquaculture attributes (Jones 1990b; Bitomsky 2008; Stevenson et al. 2013; FAO 2017).

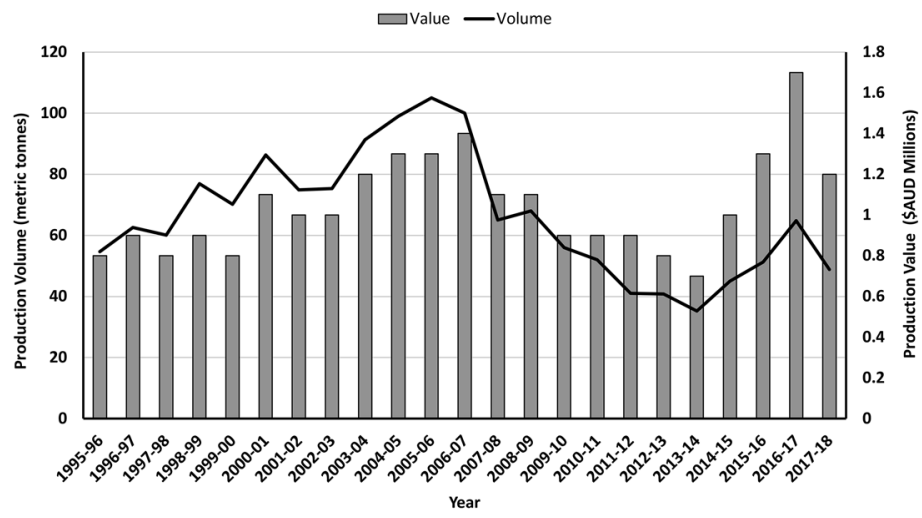

Figure 1. The trend in Queensland redclaw production quantity (tonne) and value (Australian Dollars) from 1995 to 2018 (Queensland Government 2015, 2016, 2018).

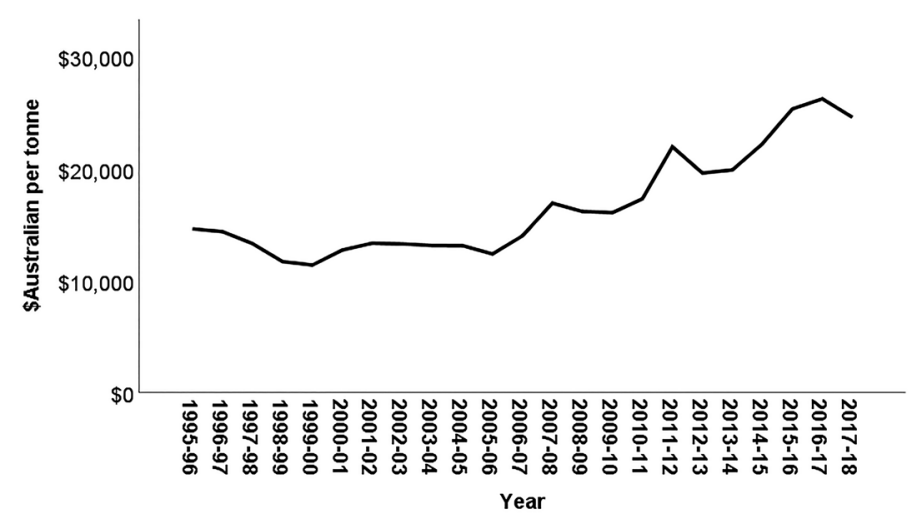

Figure 2. The trend in Queensland redclaw production in Australian Dollars per tonne from 1995 to 2018 (Queensland Government 2015, 2016, 2018).

A tolerance of high stocking densities, which increases net yield (Jones 1990b; Yeh and Rouse 1994; Barki and Karplus 2000; Jones and Ruscoe 2000; Naranjo-Páramo et al. 2004; Webster et al. 2004; Rodgers et al. 2006; FAO 2017).

A low protein diet requirement during the grow-out stage, allowing for cheaper and more sustainable food sources (Guillaume 1997; Cortés-Jacinto et al. 2003; Cortés-Jacinto et al. 2004; Cortés-Jacinto et al. 2004; Thompson et al. 2004; Cortes-Jacinto et al. 2005; Thompson et al. 2006; Metts et al. 2007; Pavasovic et al. 2007b; Saoud et al. 2008; Zenteno-Savín et al. 2008; CortésJacinto et al. 2009; Garza de Yta et al. 2011; FAO 2017).

Potential for partial or complete fishmeal replacement in formulated diets by plant-based or industry waste protein, which can reduce the price of the feed (Kondos 1990; Loya-Javellana et al. 1993; Lawrence and Jones 2002; García-Ulloa et al. 2003; Muzinic et al. 2004; Thompson et al. 2004; Campaña-Torres et al. 2005; Thompson et al. 2006; Gutiérrez and Rodríguez 2010; Garza de Yta et al. 2011; Arredondo-Figueroa et al. 2013; FAO 2017).

They can survive extended periods out of the water, up to weeks if the temperature and humidity are optimal, and therefore, 


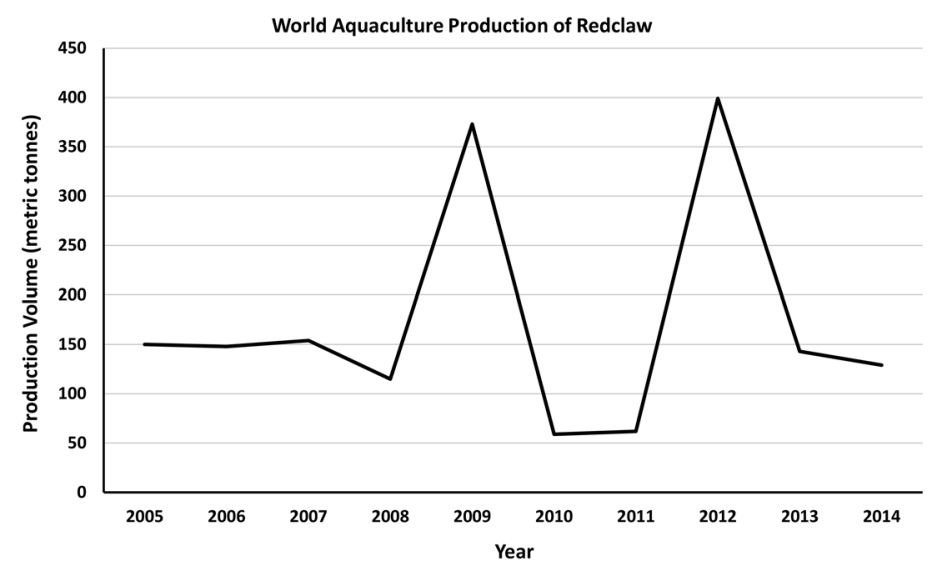

Figure 3. Global redclaw production trends from 2005 to 2014 (FAO 2017).

can be transported without water at all stages from egg to adult, thus reducing transport costs (Jones and Ruscoe 1996; FAO 2017).

Production equipment and associated technology requirement is minimal, allowing for greater ease and less cost in setting up an aquaculture facility (Cortés-Jacinto et al. 2003; Thompson et al. 2005; Saoud et al. 2008; FAO 2017).

Redclaw are tolerant of wide variations in water quality variables including $\mathrm{pH}$, dissolved oxygen, temperature and nutrient loads, allowing savings in labour, equipment and chemicals required to mitigate such variation (Thompson et al. 2004; FAO 2017).

Redclaw have osmo-regulatory capacity to tolerate salinity of up to $5 \mathrm{ppt}$ indefinitely and up to $15 \mathrm{ppt}$ for several days (Anson and Rouse 1994; Jones 1995e). This allows for greater geographic range into areas that may have slightly brackish conditions (FAO 2017), and also means redclaw can be purged and cleaned in salty water, which improves transport survival and enhances the flavour (Jones 1989).

Despite some early promotional efforts by the redclaw aquaculture industry, that generated a positive reception in markets in Australia and overseas, the major constraint to marketing has been lack of supply volume (Queensland Government 2007; Bitomsky 2008). Further active marketing is required to increase acceptance and awareness domestically, however current production volumes are still too small to support an export market (Bitomsky 2008).

The potential for aquaculture of redclaw based on climatic conditions extends across the north of Australia from northern Queensland, across the Northern Territory and to the Kimberley area of Western Australia (Queensland Government 2007). Despite the favourable conditions, the locations where farming has been successful have been confined to northern and southern Queensland, due to their proximity to markets, labour, and infrastructure. The areas where farming of redclaw is environmentally favourable in Northern Territory and Western Australia are logistically unsuitable at present due to their remoteness, limited access to labour, markets, and infrastructure.

\section{GLOBAL REDCLAW AQUACULTURE}

Redclaw has been introduced as an aquaculture species to Argentina, Barbados, Ecuador, Guatemala, Malaysia, Mauritius,
Mexico, New Caledonia, Samoa, Swaziland, and Uruguay (FAO 2016), to Belize, Indonesia, Morocco, Panama, and Spain (FAO 2017), and to the USA (Masser and Rouse 1993; Ackefors 2000), where it has shown potential for cultivation in the southeastern states (Rouse and Yeh 1995; Ackefors 2000). There has also been some redclaw aquaculture development in Israel (Karplus et al. 1995; Ackefors 2000) and China (Ackefors 1994; Ackefors $2000)$ but there are no reliable statistics available on production. Anecdotal information (e.g., availability in wet markets) suggests there is a substantial redclaw aquaculture industry in China.

Worldwide reported production of redclaw (excluding possible production from China and Hong Kong) decreased from $150 \mathrm{t}$ in 2005 to $129 \mathrm{t}$ in 2014 (FAO 2016). There have been various fluctuations in production over the years (Figure 3) and several countries have gone in and out of production (FAO 2016). A good example is Ecuador, where redclaw was introduced for aquaculture with a substantial start-up of 250 ha of ponds in 1994, but had virtually disappeared as an industry by 1998 (Romero 1998; Romero and Jimenez 2002). In Ecuador, redclaw production was initially very encouraging (Rouse 1994; Salame 1995; Romero 2002), but this was confounded by a lower farm-gate price than expected and difficulties with developing a market (Romero 1998; Romero and Jimenez 2002).

In many of the countries to which redclaw was translocated, it has become established as a minor aquaculture industry but with little growth (FAO 2017). For example, Mexico produces around

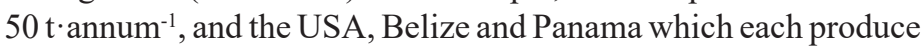
less than $10 \mathrm{t}^{\text {annum }}{ }^{-1}$ (FAO 2016). Ecuador had significant production of juveniles briefly in the late 1990s for stocking new farms, but output is now negligible. Substantial infrastructure for large scale redclaw farming activities was constructed in Spain and Morocco in the late 1990s and early 2000s, but the subsequent production is unknown (FAO 2017) and likely to be insignificant.

\section{GLOBAL CULTIVATION OF REDCLAW SEEDSTOCK}

Outside of Australia, redclaw aquaculture is limited and information on production of juvenile redclaw for supply to grow-out operations is scant. Various studies have investigated the biology and the feasibility of redclaw aquaculture in other countries, including those of Yeh and Rouse (1994); Abdu et al. (1997) and Rodríguez-Canto et al. (2002). However, few studies have examined the production of juveniles (Parnes and Sagi 2002). Calvo et al. (2011) described a method of producing craylings and one gram juveniles for use in an experiment in Argentina. In this study, berried females carrying attached eggs (= ovigerous) were placed individually in aquaria and monitored for development. Once the juveniles had reached the free-living, post larval stage 3 (= crayling) they were separated from the female and transferred into an experimental apparatus (Calvo et al. 2011). In another study, juvenile production was examined, but in a semi-intensive way and concentrated on assessing the optimum density and juvenile habitat requirements (Parnes and Sagi 2002).

In Australia, there are a range of methods for cultivation of juvenile redclaw from extensive to intensive (Jones 1995b, 1995c), and in the absence of strong evidence otherwise, it is assumed 
that this is also the case in overseas production (O'Sullivan et al. 2003). The intensification of juvenile production may be of benefit to developing markets outside of Australia as well as within, incorporating a 'best-practice' approach based on rigorous science to enhance farming efficiencies, profit, and eventual expansion of the redclaw industry.

\section{EARLY JUVENILE REDCLAW PRODUCTION, THE LATE 1980s}

The initial extensive method of producing redclaw juveniles involved little intervention in the natural breeding process, relying instead on the natural seasonal reproduction under ambient conditions. Farmers stocked production ponds with a ratio of 4 adult females to 1 adult male, and simply allowed them to breed during the summer (Stevenson et al. 2013) and produce offspring naturally to stock the pond. Development of separate juvenile cultivation techniques was considered unnecessary (Jones 1995b).

A confounding outcome of this extensive and straightforward approach to producing juveniles for grow-out was repetitive and asynchronous breeding that generated multiple cohorts (Sammy 1988; Karplus et al. 2003) within the pond. Harvesting of the production ponds revealed the multiple cohorts and significant size variation of crayfish, which is not conducive to generating a crop of consistent marketable size redclaw.

This approach, allowing natural breeding in the growout ponds, generated additional juveniles, but increased the uncontrolled density of stock, which likely results in density-dependent growth inhibition (Barki et al. 2006) and resource competition between cohorts (Jones and Ruscoe 2000). Furthermore, the disparate sizes of the crayfish and unsynchronised molting likely contributes to increased cannibalism, as small, soft post-moult crayfish are particularly vulnerable to predation by conspecifics. Therefore, in spite of the multiple breeding events, juvenile survival was low, estimated by Jones (1995b) to be no more than $5-10 \%$.

A further problem with extensive methods of producing juveniles was the potential for inbreeding due to the selection of the broodstock. Broodstock selected as the larger and fitter specimens from previous harvests are likely to be closely related (McPhee et al. 2004). Adult broodstock left in broodstock ponds throughout a summer grow-out period for juvenile production represents an opportunity cost, as these animals are unable to be sold (Stevenson et al. 2013). Using the extensive methods, output of juveniles is inconsistent as a function of the number and quality of berried females, the influence of seasonal factors (day length, water temperature), and variability in stocking (Stevenson et al. 2013).

\section{THE NEXT PHASE IN JUVENILE REDCLAW PRODUCTION, THE LATE 1990'S}

A more controlled procedure was subsequently adopted, whereby, male and female brood stock, selected for size, growth and vigour, were introduced into specifically designated broodstock ponds at a ratio of 1 adult male to 4 adult females (Stevenson et al. 2013) and density of 1 adult $\cdot \mathrm{m}^{-2}$. Once it was established that the females were berried they were separated from the males and stocked to grow-out ponds (Stevenson et al. 2013), where the offspring would be released naturally, to stock the pond. A similar method was used by Jones (1995c) where berried females were selected and staged according to their egg colour (Jones 1990b; 1995b). Females with eggs at a similar stage were stocked into a juvenile production pond. This method represented an advance in intensification that enabled a single cohort to be generated and avoiding further breeding due to absence of any mature males.

Another variation on this method involved sourcing the berried females from the harvest of other growout ponds (Stevenson et al. 2013). These berried females were stocked to ponds and left for 6-12 weeks to enable the eggs to hatch and juveniles to develop to an advanced stage of 5-15 grams, whereupon they were harvested, graded by size, and then used to stock grow-out ponds (Stevenson et al. 2013). A major problem with this approach was the difficulty of estimating the age of an animal from its size. Some of the 'juveniles' were likely to be runts - slow-growing adults (Stevenson et al. 2013), that would continue to grow slowly, and therefore, lower the value of the crop at harvest.

A variety of methods has also been applied to juvenile production for research purposes. Jones and Ruscoe (2000) produced advanced juveniles in ponds stocked with mature broodstock and left for 4 months, flow-trapping them (Jones and Curtis 1994) for grow-out experiments to examine density and size-at-stocking effects in earthen pond conditions. McPhee et al. (2004) produced craylings for experiments by inducing redclaw to mate and become berried in fiberglass breeding tanks. Water temperature $\left(26-28^{\circ} \mathrm{C}\right)$ and day length (14 hours light, 10 hours dark) were maintained to simulate mid-summer breeding conditions (McPhee et al. 2004), and berried females were then transferred to pens constructed of plastic mesh and shade cloth within traditional earthen grow-out ponds. After 4 months, advanced juveniles and female broodstock were harvested and separated (McPhee et al. 2004). At this point in the evolution of juvenile production techniques for redclaw for use in aquaculture in Australia, it appeared necessary to take more control of the production to achieve more predictability of output, to minimise disease transmission, to improve genetic quality (Stevenson et al. 2013) and to enable all farm ponds to be allocated for grow-out rather than having a proportion occupied for juvenile production.

\section{ADVANCEMENT IN METHODS OF JUVENILE REDCLAW PRODUCTION}

In 2005, the redclaw industry in north Queensland (Australia) started to embrace further intensification of juvenile production, including control of egg incubation. To facilitate this, North Queensland Crayfish Farmer's Association (NQCFA) member AquaVerde imported the Hemputin incubator system from Finland (Jones and Valverde 2020; Stevenson et al. 2013). Managed incubation was achieved by removing the eggs from the pleopods of the female at the mid-stage around 4 weeks after fertilization, then incubating them in the Hemputin system, specifically modified for redclaw. The eggs from each female (around $300-800$ eggs) were held in small $(100 \mathrm{ml})$ plastic baskets, placed in racks in a shallow water bath with a uni-directional water flow, connected to a recirculation system with UV sterilization and a biological filter. Once the eggs hatch, they are left in the incubator baskets 
for 2 moults, until the crayling stage is reached. The craylings thus produced are robust and suitable for transport. The advantages of this artificial incubation approach were that the eggs could be treated to reduce pathogens, processed in discrete cohorts, and batched for commercial orders. This then allowed redclaw growout farmers to purchase such hatchery generated craylings and allocate all of their ponds to on-growing, ordering craylings for new stockings as required.

A significant improvement in management that hatcheryproduced craylings provided was that batches of a fixed number, of known-age craylings could be introduced to the grow-out ponds to achieve a specific density of stock in the pond. By harvesting such ponds at 6 to 9 months (age at first maturity), there is little likelihood of any breeding that would confound the stocking (Barki et al. 2006). Because the hatchery-reared craylings would be of same age and size, the consistency would help mitigate cannibalism, as the crayfish would moult more synchronously (Ghanawi and Saoud 2012). This is in stark contrast with earlier on-farm juvenile production that typically involved stocking with a wide variation in size and, therefore, increased opportunity for cannibalism (Ghanawi and Saoud 2012). A further advantage of the hatchery approach, was the capacity to select crayfish for breeding that demonstrated superior characteristics, including size at age and robustness, leading to stock improvement over time.

With the establishment of a hatchery supply of craylings, redclaw farmers now have the opportunity to focus entirely on grow-out, purchasing seedstock only as required. This is a major advancement that brings redclaw aquaculture in line with other successful aquaculture industries that have dedicated hatcheries to supply the seedstock (Jones and Valverde 2020; Stevenson et al. 2013).

Predictable and consistent seedstock production from hatchery operations is likely a key factor in the expansion of redclaw aquaculture, both within Australia and abroad. Nevertheless, the hatchery technology is relatively new and the protocols and methods require further refinement. It remains unclear whether stocking craylings to grow-out ponds is optimal or whether an intermediary nursing phase is necessary to on-grow craylings to advanced juvenile stage prior to pond stocking. There is justifiable concern that craylings are highly vulnerable to predation, and that survival through the grow-out may be improved by stocking grow-out ponds at a more advanced juvenile stage. Research will be necessary to resolve this issue, learning from previous research on redclaw seedstock production methods and performing new research to define a best-practice model for producing juveniles for grow-out operations. The aspects requiring further research to perfect the hatchery approach for redclaw include; nursery diet, optimal nursery period, temperature, provision of habitat, stocking density and prevention of cannibalism.

\section{NURSERY DIET}

A considerable body of research has been published on redclaw nutrition for the grow out phase, from juvenile (Jones 1995a, 1995b, 1995c, 1995d; Meade and Watts 1995; Anson and Rouse 1996; Fletcher and Warburton 1997; Loya-Javellana and Fielder 1997; Ruscoe et al. 2000; Cortés-Jacinto et al. 2003; Thompson et al. 2003a, 2003b; Cortés-Jacinto et al. 2004a, 2004b; Hernandez et al. 2004; Muzinic et al. 2004; Thompson et al. 2004; Cortés-Jacinto et al. 2005; López-López et al. 2005; Thompson et al. 2005; Campaña-Torres et al. 2006; Metts et al. 2007; Saoud et al. 2008; Zenteno-Savín et al. 2008; Gutiérrez and Rodríguez 2010; Thompson et al. 2010; Garza de Yta et al. 2011; Saoud et al. 2012; Viau et al. 2012; Zhu et al. 2013; Dammannagoda et al. 2015; Pirozzi et al. 2015; Volpe et al. 2015) through to marketable size ( $c a .100 \mathrm{~g}$ ) (Loya-Javellana et al. 1993; Asgari 2004; Pavasovic et al. 2006, 2007a, 2007b; Campaña-Torres et al. 2008; Rodriguez-Gonzalez et al. 2009a, 2009b; Li et al. 2011; Saoud et al. 2012; Pirozzi et al. 2015). As food can constitute up to $70 \%$ of the operating cost in aquaculture (Thompson et al. 2003a; Metts et al. 2007) cost-effectiveness of the feed is a critical factor for aquaculture worldwide. The rising cost and falling supply of fishmeal (and issues regarding its source and sustainability) have stimulated research experiments with redclaw to find cheaper and more sustainable alternatives. Studies have now examined plantbased and terrestrial animal sources for the protein component in aqua feeds (Jones and Ruscoe 1996; García-Ulloa et al. 2003; Muzinic et al. 2004; Campaña-Torres et al. 2005; Thompson et al. 2005, 2006; Metts et al. 2007; Gutiérrez and Rodríguez 2010; Ranjan and Bavitha 2015). A number of studies have demonstrated that not only can the protein be of plant origin, but the palatability and efficacy of such diets for the grow-out of redclaw is high (Muzinic et al. 2004; Thompson et al. 2005, 2006).

The protein requirement for good growth and efficient food conversion (food conversion ration: FCR $=$ Feed Given / Animal Weight Gain) in redclaw has received considerable attention, with a number of studies identifying optimal protein inclusion rates in the diet (Cortés-Jacinto et al. 2003, 2004a, 2004b; Muzinic et al. 2004; Thompson et al. 2004; Campaña-Torres et al. 2005; CortesJacinto et al. 2005; Thompson et al. 2005; Rodríguez-González et al. 2006; Thompson et al. 2006; Metts et al. 2007; Pavasovic et al. 2007b; Saoud et al. 2008; Zenteno-Savín et al. 2008; CortésJacinto et al. 2009; Rodríguez-González et al. 2009a; Gutiérrez and Rodríguez 2010; Garza de Yta et al. 2011; Rodríguez-González et al. 2011; Arredondo-Figueroa et al. 2013; Stumpf et al. 2014; Ranjan and Bavitha 2015) that are specific to the life history stage of the crayfish (Cortés-Jacinto et al. 2009). These studies indicate that the protein requirement falls as redclaws age. Cortés-Jacinto et al. (2009) indicate that juvenile redclaw require 31 to $34 \%$ protein and pre-adults $(<50 \mathrm{~g})$ require $25.6 \%$ protein (Cortés-Jacinto et al. 2004b). Jones (1995c) observation that craylings and early stage juveniles $<0.6 \mathrm{~g}$ consume zooplankton, may reflect a higher protein requirement.

Lipids are also a critical component of the diet that affects growth and health, and many studies have examined lipid requirements for redclaw (Hernandez-Vergara et al. 2003; Thompson et al. 2003a, 2003b; Cortes-Jacinto et al. 2005; Campaña-Torres et al. 2006, 2008; Zenteno-Savín et al. 2008; Rodríguez-González et al. 2009b; Thompson et al. 2010; Li et al. 2011; Zhu et al. 2013). Cortés-Jacinto et al. (2003) suggest that the optimal level of dietary digestible lipid is $75 \mathrm{~g} \cdot \mathrm{kg}^{-1}$ for small $(1.08 \pm 0.34 \mathrm{~g})$ juveniles, while others suggest a dietary lipid level 
of $87 \mathrm{~g} \cdot \mathrm{kg}^{-1}$ to optimize egg quality for spawning females $(23 \pm 3$ g) (Rodríguez-González et al. 2009b). Further studies have also examined dietary lipid levels and concluded that $80 \mathrm{~g} \cdot \mathrm{kg}^{-1}$ satisfied the requirements for optimal growth, prevented oxidative stress and protected immune function integrity in small juveniles ranging from 0.7-1.54 g (Cortés-Jacinto et al. 2005; Zenteno-Savín et al. 2008). Hernandez-Vergara et al. (2003) found that $42 \mathrm{~g} \cdot \mathrm{kg}^{-1}$ dietary lipids were acceptable for larger juveniles $(4.08 \pm 0.2 \mathrm{~g})$ if natural food sources were available to supplement the diet provided. In contrast to protein, the dietary lipid requirement does not appear to vary with the life history stage of redclaw (Guillaume 1997; Campaña 2001; Joaquí and Montes 2001; Cortés-Jacinto et al. 2004a, 2005; Arredondo-Figueroa et al. 2013).

Carbohydrates are another essential component of the diet used to satisfy energy requirements (Zhu et al. 2013), which contribute to the formation of steroids and fatty acids, and assist in glycogen storage and chitin synthesis (Parvathy 1971; Dall et al. 1991; Ahamed Ali 1993; Sánchez-Paz et al. 2006; Saoud et al. 2012). Commercially, there is an economic imperative to maximize carbohydrate inclusion in formulated diets, as it can be used as an inexpensive filler (Saoud et al. 2012). Typically, carbohydrate content is maximized and protein and lipid inclusion is minimized on the basis of ingredient cost (Campaña-Torres et al. 2006, 2008; Zhu et al. 2013) balanced against effective and efficient utilisation for somatic growth (Sedgwick 1979; Campaña-Torres et al. 2008). Carbohydrates in the diet can also have a protein sparing effect, preventing catabolism (Sedgwick 1979; D'Abramo and Robinson 1989; Pillay 1990; Guillaume and Choubert 2001; Wouters et al. 2001; Saoud et al. 2012).

Zhu et al. (2013) found that the best ration of carbohydrates to lipids for redclaw was $3.6: 1$, translating to a proportion of $290.10 \mathrm{~g} \cdot \mathrm{kg}^{-1}$ carbohydrates and $80.70 \mathrm{~g} \cdot \mathrm{kg}^{-1}$ lipids for optimal digestive and hepatic enzyme activities, body composition and growth performance in juveniles $(1.54 \pm 0.02 \mathrm{~g})$. Conversely, in digestibility trials, Campaña-Torres et al. (2006) and CampañaTorres et al. (2008) found that an equivalent proportion of plantderived carbohydrates $\left(150 \mathrm{~g} \cdot \mathrm{kg}^{-1}\right.$ for $3.62 \pm 1.35 \mathrm{~g}$ juveniles, 2006 study; $145 \mathrm{~g} \cdot \mathrm{kg}^{-1} 10 \pm 0.8 \mathrm{~g}$ pre-adult, 2008 study) containing a high cellulose content were similarly effective for the redclaw of different size. It has been demonstrated that redclaw can assimilate cellulose (Xue et al. 1999; Pavasovic et al. 2006; Campaña-Torres et al. 2008) due to $\alpha$-amylase cellulose laminarinase activity in the redclaw alimentary tract (Figueiredo et al. 2001; Campaña-Torres et al. 2008) and the presence of $p$-nitrophenyl glycosidases in the gastric fluids (Figueiredo et al. 2001; Campaña-Torres et al. 2008).

Despite the considerable body of work on examining carbohydrate requirements for redclaw, none of it has applied to craylings $(\leq 0.02 \mathrm{~g})$. Thompson et al. (2003a) conducted an experiment with craylings at $0.02 \mathrm{~g}$, but examined only practical diets with or without supplemental lecithin or cholesterol. Other studies assessing carbohydrate requirements either linked them to lipids (Campaña-Torres et al. 2008; Zhu et al. 2013) and/ or used larger juveniles (Campaña-Torres et al. 2006; Zhu et al. 2013) or sub adult animals (Campaña-Torres et al. 2008). There is a knowledge gap concerning the appropriate proportion of carbohydrate in the diet of craylings, that is likely to be of importance due to the known ontogenetic diet shift which most crayfish exhibit (Saoud et al. 2012). Adult freshwater crayfish generally consume greater amounts of macrophytes and detritus in their diets, whereas juveniles feed largely on invertebrates (Mason 1975; Loya-Javellana et al. 1993; Lodge and Hill 1994; Momot 1995; Nyström 2002; Saoud et al. 2012).

Figueiredo and Anderson (2003) reported that small juvenile redclaw from $5 \mathrm{~mm}$ (carapace length), which had been recently released from the female, had high levels of protease and low levels of carbohydrases in their hepatopancreas, which reversed in abundance in larger animals, presumably as there was increased preference for plant-derived food as the crayfish grew. Carbohydrase activity increased in redclaw up to $100 \mathrm{~mm}$ in length peaking at $140 \mathrm{~mm}$ (total length) (Figueiredo and Anderson 2003) which is the size where a preference for plant material has been documented (Figueiredo and Anderson 2003). Cellulase was present in all free-living stages, indicating an ability to digest cellulose at all life stages (Figueiredo and Anderson 2003). The correlations between enzyme levels and diet and feeding habits reflect the developmental stage of the animal and the morphological changes which are occurring in the gut (Lovett and Felder 1990; Figueiredo and Anderson 2003), and hence the ontogenetic diet shift (Saoud et al. 2012). The evidence is clear for an ontogenetic shift in the dietary requirements from juveniles to adult, but little is known about the specific requirements of the crayling stage.

\section{ONTOGENETIC DIET CHANGE}

There are challenges in developing manufactured diets that account for the specific nutrition required at successive life stages following the transition from endogenous to exogenous feeding (García-Guerrero et al. 2003a) and through the ontogenetic and developmental changes (Lovett and Felder 1990; Figueiredo and Anderson 2003) from crayling to advanced juvenile and on to adult. It is likely that different diet formulations will be required for different life stages of redclaw.

There are several physical properties for a manufactured diet which also warrant discussion. A nursery diet which takes redclaw craylings through to a more advanced size would require good stability and durability in water due to the periodic nature of feeding (Ruscoe et al. 2005) and texture, pellet size and moisture content also require evaluation for suitability (Ruscoe et al. 2005; Volpe et al. 2015). Furthermore, the morphology and mechanical abilities of the mouthparts of juveniles and large adults have been explored (Loya-Javellana and Fielder 1997) and this information needs to be applied to the manufactured diet.

Early juvenile redclaw have sharply pointed teeth on the small, third maxilliped and mandible, useful in handling small animals as food, combined with reasonably long setae around the margins of the mouthparts which could be used to capture prey (Barker and Gibson 1977; Lavalli and Factor 1992, 1995; Loya-Javellana and Fielder 1997). The anterior pointed accessory tooth to the left of the incisor ridge in young juveniles may also be consistent with raptorial feeding (Loya-Javellana and Fielder 1997). As redclaw develop into young adults the teeth become less pointed but larger, reflecting a decline in small animals as food, increasing 
macrophagy and an ability to cut plant material (Loya-Javellana and Fielder 1997). The capabilities of the mouthparts at these particular stages should be taken into account in the design of the manufactured food so it best meets their morphological capacity.

Another approach which has been examined for crayling and early juvenile diet is to look at natural food sources, using them exclusively or supplemented with a manufactured feed. Anson and Rouse (1996) trialled and compared various commerciallyproduced feeds (crawfish-feed, rabbit-chow, trout-chow, shrimpfeed, Biodiet, crustacean reference diet, Shrimp-el-etts) with live Artemia nauplii, catfish muscle, and squid mantle, and found that for the first two weeks, craylings and early stage juveniles (ca.20 mg) showed improved growth and survival when fed Artemia or a combination of Artemia and a commercial diet. Jones (1995c) performed a 39 day trial on newly-hatched $(c a .20 \mathrm{mg}$ ) craylings comparing fresh zooplankton (comprising cladocerans [Moina spp.], copepods, and chironomid larvae) with commercially produced 'Frippak' Flake and found that zooplankton supported the best growth. A confounding result however, was poor survival, which was unaccounted for but appeared to be related to an interaction with a floating water plant Pistia stratiodes Linnaeus, that was provided as a shelter. Meade and Watts (1995) compared commercial, formulated feeds (AB UAB Research Foundation Formulation, Crayfish Feed, Catfish Floater, Shrimp Grower, Post-larval Granules and Shrimp Grower Pellets) with naturallysourced feeds (brine shrimp flakes, freeze-dried krill, hatchfry encapsulation, powdered spirulina) and found the best results over 10 weeks with the $\mathrm{AB}$ feed (30\% protein, $10 \%$ lipids, $10 \%$ carbohydrate). Substantial weight gain was recorded, combined with a survival of $>95 \%$ and it supported the notion that the culture of redclaw juveniles can be successful using formulated feeds (Meade and Watts 1995). It should be noted that the 10 week trial period of the Meade and Watts (1995) research, may have skewed the results as any advantage of the 'natural' feeds may have been significant only in the first two weeks as per Anson and Rouse (1996). They suggested the 'naturally-sourced' feeds offerred may have been undigestible during later developmental stages (Campaña-Torres et al. 2006) or had become unpalatable.

Although there appears to be evidence that natural feeds, especially zooplankton (Tcherkashina 1977; Jones 1995c) and decayed plant material (which may hold epibenthic and sessile epiphytic organisms), may have a benefit in crayling and early juvenile growth and survival (D'Abramo et al. 1985; Celada et al. 1989; Mitchell and Collins 1989; Brown et al. 1992; McClain et al. 1992; Loya-Javellana et al. 1993), supplemental feeding with a nutritionally-balanced manufactured feed as the juveniles grow older is likely to provide essential nutrients for maximum growth and be better assimilated as they age (Anson and Rouse 1996). It would be useful to gather data on feeding craylings and early stage juveniles not only for different diet formulations, but also incorporating the food ration and feeding frequency to determine optimal feeding practice.

For the advancement of the redclaw industry, further research is required, specifically targeting the crayling and eary juvenile stages, on development of an effective diet formulation, natural feed or combination diet, source of ingredients, the inclusion rates of protein, lipids and carbohydrates, and the feeding husbandry in regard to rations and feeding frequency.

\section{NURSERY PHASE}

Commercial aquaculture industries for most crustaceans involve distinct phases from hatchery through nursery to grow-out (Parnes and Sagi 2002). The development of commercial redclaw hatcheries in Australia revealed challenges with improving the vigour and resiliance of craylings destined for release into grow-out ponds (Stevenson et al. 2013). Recently-hatched craylings stocked directly into grow-out ponds can result in poor and unpredictable survival rates (Garza de Yta 2009). Holding craylings for a nursery period prior to release into grow-out ponds may hold benefits in terms of subsequent survival and growth to harvest (Garza de Yta 2009). It is envisaged the nursery phase would nurture the crayling to an advanced juvenile size, sufficiently robust for on-growing. Redclaw growers in Mexico typically stock grow-out ponds with juveniles above $1 \mathrm{~g}$ to ensure higher survival rates (Garza de Yta 2009), for the same reasons an early study in Australia (Jones and Ruscoe 1996) recommended stocking advanced juveniles between 5 and $10 \mathrm{~g}$. The nursery phase for many species is typically high cost, due to high density and intensive management, therefore its duration should be limited. Jones (1995b) examined holding newly released craylings for a nursery period in individual tanks with two types of habitat: fiberglass fly-screen mesh strips suspended from floats; and timber frames with fly-screen mesh strips woven through plastic trellis mesh (Smith and Sandifer 1979; Jones 1995b). The feeding regime was commercial Flake 'Frippak' combined with proportions of either fresh or frozen zooplankton. The highest mean size of $0.427 \mathrm{~g}$ was achieved in 41 days at a survival rate of $52.3 \%$ fed 'Frippak' plus 100\% frozen zooplankton (Jones 1995b).

Parnes and Sagi (2002) examined a nursery period for newlyreleased craylings from closely synchronised ovigerous female broodstock, where they utilised seaweed-like plastic elements for habitat within fibreglass tanks. Over a period of 35-40 days the craylings were fed grated potatoes, carrots and commercial fish pellets; the average male and female weights at the end were $0.54 \pm 0.02 \mathrm{~g}(n=432)$ and $0.49 \pm 0.02 \mathrm{~g}(n=376)$, respectively (Parnes and Sagi 2002). This study showed that by the addition of a three dimensional habitat/substrate, craylings would effectively utilise almost the entire volume of the tank, thereby increasing the stocking capacity as compared to the two dimensional benthic space of a tank with no habitat/substrate, and that a uniform-sized crayling population would minimise cannibalistic interactions between conspecifics.

In a series of three experiments in Alabama, USA, Garza de Yta (2009) evaluated different hatchery-nursery proceedures to test for maximum survival, final weight and production of advanced juveniles. The factors were water depth, broodstock stocking density and nursery period duration. In the first experiment, tanks were stocked with nine females $\operatorname{tank}^{-1}$ at a $100 \mathrm{~mm}$ or 200 $\mathrm{mm}$ water depth or 18 females at $200 \mathrm{~mm}$. A 31 day nursery period was initiated after all the craylings had released from the female broodstock within a $96 \mathrm{~h}$ time period. Craylings were fed commercial crayfish pellets (30\% protein, $8 \%$ lipid) at a rate of $10 \%$ of body weight and provided with bundles of onion-bag mesh 
for shelter. The second experiment held 8, 12, 16, 20 or 24 berried females (densities of 2.8, 4.2, 5.6, 6.9 and 8.4 females $\cdot \mathrm{m}^{-2}$ ) in similar tanks with the same protocols and a 30 day nursery period was applied. In the same way, a third experiment tested stocking $8,12,16$ berried females $\left(2.8,4.2,5.6\right.$ females per $\left.\mathrm{m}^{2}\right)$ for nursery periods of 20,30 or 40 days.

At the conclusion of this set of experiments it was found that a stocking density of 12,16 or 20 berried females $\operatorname{tank}^{-1}(4.2,5.6$ or 6.9 females $\cdot \mathrm{m}^{-2}$ ) produced the best output in terms of juvenile production based on survival and average weight in a hatchery/ nursery period (Garza de Yta 2009). Survival was best at 30 days and as the growth appeared to slow from 30 to 40 days and survival decreased at 40 days, the optimal period for the hatchery/nursery phase was 30 days (Garza de Yta 2009). Water depth as a treatment only indicated no significant effect. Unfortunately, habitat/shelter provisions for the juveniles in the form of onion bag mesh was not used as a treatment, and this may have had an effect on the survival and harvest weight of the juveniles, and a potentially confounding effect on the results. If onion bag mesh had been provided for in terms of expected number of juveniles, it may have clarified the results.

Although the Garza de Yta (2009) survival rates were lower compared to other nursery experiments (Jones 1995b; Masser and Rouse 1997) the size of the craylings at 30 days was comparable to the size of craylings produced by Jones (1995b) and Parnes and Sagi (2002) over a period of 41 and 40 days respectively (Jones $0.427 \mathrm{~g}$, Parnes and Sagi [male] $0.54 \pm 0.02 \mathrm{~g}$ [female] $0.49 \pm 0.02$ $\mathrm{g})$. Regardless of the effect of female broodstock density the mean total production, survival and, therefore, final biomass was best at the 30 days (Garza de Yta 2009). This nursery duration maximised the total production of advanced craylings without sacrificing average weight output (Garza de Yta 2009). However, the harvest size and survival rates for hatchery-nursery phase require substantial increases (Garza de Yta 2009) to assist the advancement and development of the production of redclaw seedstock.

\section{TEMPERATURE}

Environmental temperature is an integral component of the physiological capacity of an organism to consume and convert resources such as food into growth, reproduction, and survival. This is particularly important for organisms which cannot control their internal body temperature, and are forced to match their environmental temperature. This is the case for thermoconformers in marine and freshwater environments which are beholden to environmental thermal regimes.

Redclaw crayfish are thermoconformers and like other arthropods, such as insects, development and growth are positively correlated with temperature, within an optimum range. For insects the concept of "degree days" was developed (Higley et al. 1986) to describe the rate of development over time, in relation to temperature. For redclaw, the duration of the successive developmental stages from egg hatch, through two molts to crayling, and through each juvenile stage will be correlated with temperature. For development of nursery technology, it is essential to identify the most advantageous temperature for each stage, balancing development time and survival (Jones 1990b; King 1994; Yeh and Rouse 1994; Jones 1995b, 1995c; Zhao et al. 2000; Garcia-Guerrero et al. 2003a; Karplus et al. 2003; De Bock and López Greco 2009).

Vazquez et al. (2004) showed that it is possible to alter the gender proportion of sexually undifferentiated juveniles to a preponderance of males, by increasing temperature during culture. De Bock and López Greco (2009) also showed higher temperatures can increase the proportion of males, which is a favourable characteristic in redclaw as males grow faster (Curtis and Jones 1995; Manor et al. 2002, 2004; Rodgers et al. 2006). It may be of economic value to more specifically identify the temperature to achieve the increased proportion of males.

A number of studies which have looked at temperature for culture of craylings and early stage juveniles have suggested an optimal water temperature of $27^{\circ} \mathrm{C}$ (Anson and Rouse 1996; Barki et al. 1997; Cortés-Jacinto et al. 2003; Campaña-Torres et al. 2005, 2008; Calvo et al. 2011, 2013) whereas García-Guerrero et al. (2003b) recommended an optimal temperature of $22-25^{\circ} \mathrm{C}$ for aquaculture of early stage redclaw.

In summary, a nursery phase which would involve managed culture of redclaw juveniles from the crayling stage, will have additional cost. It is important to identify the optimal temperature to culture the juveniles to attain fastest possible growth without negatively impacting survival. There have been no published studies to date that address this issue and such knowledge may greatly enhance the prospects of the industry.

\section{HABITAT}

Barki et al. (1997) suggest that cannibalism and predation are major causes of mortality during grow-out, and this may also apply to the nursery phase and has been shown in experiments where craylings were stocked into fiberglass tanks (Jones 1990b, 1995b) and also with craylings stocked to experimental tanks in high densities with no refuge (Barki et al. 1997). Redclaw appear to be cannibalized whilst moulting (Barki et al. 1997), and there is evidence that redclaw avoid cannibalism by positioning themselves away from conspecifics in the shallow margins of earthen ponds or on top of habitat structures (Jones and Ruscoe 2001). Several studies have demonstrated the effectiveness of various materials in providing habitat for advanced juvenile and adult redclaw in ponds (Jones 1995d; Jones and Ruscoe 2001) that supported increased survival through presumed mitigation of conspecific predation. Jones and Ruscoe (2001) simulated macrophytes and Viau and Rodríguez (2009) used various-sized pvc pipes for habitat. Juvenile redclaw will take refuge in onion bags or mesh bundles which simulate macrophytes and which provide shelter and protection, and also decrease the density by providing larger areas of substrate.

The are no published data on effects of shelter/habitat on redclaw at the crayling stage, despite cannibalism being evident at this earliest free-living stage. Some candidates for suitable habitat for craylings include bundles of micro tubes (drinking straw diameter), which represent a scaled-down version of the bundles of pipes commonly used for older redclaw in ponds (Jones and Ruscoe, 2001), onion bag mesh, or crevice type shelters as commonly used as an artificial habitat for capturing lobster pueruli 
(Priyambodo et al. 2015, 2017). Specific research is warranted to understand crayling behaviour and the impact of provision of shelter on survival and growth in a nursery phase.

\section{DENSITY}

Stocking density is another important factor which has a significant effect on redclaw production (Pinto and Rouse 1996; Jones and Ruscoe 2000; Naranjo-Páramo et al. 2004). Size at stocking and stocking density significantly impact yield for many crustacean species in aquaculture (Allan and Maguire 1992; Geddes et al. 1993; Daniels et al. 1995; Morrissy et al. 1995; Tidwell et al. 1999). For redclaw, it has been demonstrated that mean harvest weight is inversely related to original stocking density (Pinto and Rouse 1996; Jones and Ruscoe 2000; NaranjoPáramo et al. 2004; Rodgers et al. 2006). Furthermore, yields are often directly related to density. Naranjo-Páramo et al. (2004) and Jones and Ruscoe (2000) found that mean food quotients, yields, and economic returns significantly increased with increased stocking size and density. The juveniles in that study were of an advanced size ( $4.71 \mathrm{~g}$ and $16.89 \mathrm{~g}$ ) and the stocking densities were relatively low $\left(3,9,15\right.$ crayfish $\left.\cdot \mathrm{m}^{-2}\right)$. There has been no specific examination of pond stocking density for craylings.

Size variability within a redclaw population can have a negative impact on smaller crayfish due to hierarchical dominance/ subordinance behaviour (Karplus and Barki 2004). Karplus and Barki (2004) found the growth of small males was reduced by $50 \%$ when in contact with larger males, and they attributed this to an increased inter-moult period and reduction in size increment per moult. Competition for food fed ad libitum when it was a defendable resource was found to contribute to this relationship, however the addition of shelters to minimize interactions in nursery units resulted in an increase in juvenile weight (Karplus et al. 1995). This suggests that habitat may play an important role in attenuating the negative effects of high density (Jones and Ruscoe 2000). Conversely, Barki et al. (2006) used individual compartments to overcome social-dependent density limitations in a battery culture experiment. Male redclaw showed a lower growth rate when surrounded by neighbours, small crayfish surrounded by large neighbours also showed lower growth rates. Shelter alone may not be the solution to density growth rate suppression. The number and size of neighbours also have an effect. NaranjoPáramo et al. (2004) conducted a nursery-stage study using $1.3 \mathrm{~g}$ juveniles in gravel-lined nursery ponds. They examined stocking densities of redclaw at 5, 6, 8, 11 and 20 crayfish $\cdot \mathrm{m}^{-2}$ grown for 80 days to see which densities could achieve a mean weight of at least $25 \mathrm{~g}$ in that time. The study found that densities of $11 \mathrm{crayfish} \cdot \mathrm{m}^{-2}$ and lower achieved this, but at $20 \mathrm{~m}^{-2}$, individual growth was significantly less.

Aquatic organisms in general display an inverse linear relationship between density and body size (Duarte et al. 1987). This is a fundamental regularity across all terrestrial and aquatic systems, showing that organisms use the space of $1 / 3$ power of their body size (Duarte et al. 1987). Such a density effect however can be mitigated through the addition of habitat as it provides additional protection and space for the animals (Jones 1990b, 1995c). Extremely low stocking density of animals may also have a negative impact if the carrying capacity of the environment is not fully used, leading to loss of production, higher per unit production cost and a loss of efficiency. For commercial aquaculture production, stocking density and its effects on overall production and mean harvest weight must be understood to achieve optimal economic outcomes. If redclaw craylings are to be cultured in a discrete nursery phase, research of stocking density effects will be necessary to determine optimal stocking practices. Determining the highest stocking density possible with the provision of habitat at an optimal level will maximise production numbers, lower costs per unit and increase efficiency.

\section{SUMMARY}

The development of artificial incubation 'hatchery' systems to produce redclaw crayfish craylings as seedstock for grow-out operations is new technology. The stimulus for such development was initially the desire to produce specific pathogen free (SPF) stock of a selectively bred 'domesticated' genetic strain (Stevenson et al. 2013). Prior to this new technology, production of redclaw juveniles was achieved by managing natural reproduction in ponds and sometimes tanks (Jones 1989). That 'traditional' approach still dominates the industry as the hatchery approach is developmental and not yet fully commercial. The disadvantages of the traditional approach are:

- in-pond breeding events which produce numerous extra cohorts and unknown densities (Sammy 1988; Jones et al. 2000; Karplus et al. 2003; Barki et al. 2006)

- low survival, likely $5-10 \%$ (Jones 1995b)

- inbreeding (McPhee et al. 2004)

- seasonal factors affect harvest success (Stevenson et al. 2013)

- inconsistent harvest due to inconsistent stocking (Stevenson et al. 2013)

- effort and money spent raising seedstock in ponds is better spent on grow-out (Stevenson et al. 2013)

An intensive hatchery approach to crayling production provides significant advantages including:

- production of specific pathogen-free $[\mathrm{SPF}]$ animals (Stevenson et al. 2013)

- selectively breed for faster and more uniform growth (Stevenson et al. 2013)

- combat inbreeding depression (Stevenson et al. 2013)

- produce stock all year round (Stevenson et al. 2013)

\section{FUTURE RESEARCH DIRECTIONS}

As with most aquaculture enterprises, production of high quality seedstock is a critical part of a successful operation. Inherent within this intensification process is the concept of minimising cost and introducing economies of scale to further enhance profitability. Effective hatchery technology will assist redclaw aquaculture to become more intensive and profitable. It is envisaged that a small number of dedicated hatcheries will provide the seedstock to the broader redclaw grow-out industry, in a fashion similar to that of most commercially successful aquaculture industries. For redclaw hatchery technology to become fully commercial, greater 
consistency of survival through the incubation phase is required, along with standard operating procedures for the subsequent nursing of the craylings.

The research required includes formulation of a specific crayling nursery diet, optimization of feeding husbandry (feeding frequency, ration, feed delivery, feed form) and management protocols that maximize survival and quality of the juveniles produced (García-Guerrero et al. 2003a). The time that craylings are held in a nursery period and which temperature, type and quantity of habitat and stocking density need to be established.

The diet itself must contain protein, lipids and carbohydrates in the most appropriate ratio, at a specific energy and digestibility value, and be delivered within a water-stable pellet of a size ideal for crayling mouth parts. The onset of the ontogenetic change from crayling diet to the next stage must be identified. This will require a change in protein, lipid, and carbohydrate ratio in the feed, as evidenced by the changes in amino acid and lipid content within the animal itself at this life stage (García-Guerrero et al. 2003a).

The optimal period to hold the craylings to maximize survival and growth needs to be explored. The duration of the nursery phase will be a balance between cost and achieving a juvenile size that is optimal for pond stocking in relation to subsequent growth and survival through grow-out.

The most advantageous temperature to culture craylings for quickest growth, and highest survival, in a nursery phase is yet to be determined. Higher temperature may increase growth rate but at the expense of survival (King 1994; García-Ulloa et al. 2003), while low temperature will support slow growth but higher survival rates (King 1994; García-Ulloa et al. 2003). The intersection of these two factors to determine the optimal temperature has yet to be established.

A nursery phase which provides the best dietary parameters and temperature may help moderate the problem of cannibalism. The reasonably poor survival shown in grow-out operations using craylings may be mitigated by introducing more advanced juveniles. However, since it has not yet been established why there appears to be such a high level of cannibalism, other possible factors need to be explored. The provision of structure within a nursery period would give the animals somewhere to hide whilst going through ecdysis, as very small crayfish moult frequently (Jones and Ruscoe 2000) and this is when they are preyed upon by conspecifics (Ghanawi and Saoud 2012). At the nursery stage, experiments could be conducted to determine the optimal habitat. This would also assist in lowering the effective stocking density and allowing more animals to be held.

Anursery phase immediately following the hatchery production would nurture the crayfish from crayling to an advanced juvenile and provide potential positive benefits to the redclaw aquaculture industry. These potential benefits include a reduction in variability of survival through grow-out, which could reduce the risk to the farmer of unknown crop size. Hatchery/nursery operations can remove the technical side of producing seedstock from the average farmer so they can concentrate on the grow-out. This is a typical scenario for more mature aquaculture industries such as those for Barramundi (Lates calcarifer (Bloch)), where once the research and development phase is over many hatcheries are set up for ease of grow-out, more predictable yields, and lower transport costs.

The final process in the intensification of a combined hatchery/nursery production phase for redclaw would be to gather together the results from all the research and produce a best practice management protocol for producing juveniles for growout operations. It is likely that a nursery phase for redclaw will provide more surety, interest and investment in what is a potentially highly profitable industry, producing high value food, employment and rural income in Australia and subtropical and tropical regions elsewhere in the world.

\section{ACKNOWLEDGMENTS}

This review was prepared as part of a $\mathrm{PhD}$ program of the first author and in association with a research project supported by the Australian Government Rural Industries Research and Development Corporation (now AgriFutures Australia), project number PRJ00938. We thank the Freshwater Crayfish editor and the two anonymous reviewers for their useful comments and suggestions.

\section{LITERATURE CITED}

Abdu U, Harpaz S and Karplus H (1997). Culture of the Australian red-claw crayfish (Cherax quadricarinatus) in Israel. Israeli Journal of Aquaculture - Bamidgeh 49(4):222 229. doi: $10.1016 / \mathrm{s} 0044-8486(98) 00290-7$

ACKEFORS H (1994). Recent progress in Australian crayfish culture. World Aquaculture 25(4):14-19.

ACKEFORS HEG (2000). Freshwater crayfish farming technology in the 1990s: a European and global perspective. Fish and Fisheries 1(4):337-359. doi: 10.1046/j.1467-2979.2000.00023.x

Ahamed AS (1993). Evaluation of different carbohydrates in the diet of the prawn Penaeus indicus. Journal of Aquaculture in the Tropics 8(1):13-23.

Allan GL ANd Maguire GB (1992). Effects of stocking density on production of Penaeus monodon Fabricius in model farming ponds. Aquaculture 107(1):49-66. doi: 10.1016/00448486(92)90049-Q

Anson KJ AND Rouse DB (1994). Effects of salinity on hatching and post-hatch survival of the Australian red claw crayfish Cherax quadricarinatus. Journal of the World Aquaculture Society 25(2):277-280. doi: 10.1111/j.1749-7345.1994. tb00191.x

ANSON KJ AND Rouse DB (1996). Evaluation of several commercial feeds and Crustacean Reference Diet for juvenile Australian red claw crayfish, Cherax quadricarinatus. Journal of Applied Aquaculture 6(1):65-76. doi: 10.1300/J028v06n01_06

Arredondo-Figueroa JL, Ponce-Palafox JT, ShiraiMatsumoto K, Pérez-Zavaleta Á, Barriga-Sosa idLÁ AND RuIz LunA A (2013). Effects of including shrimp protein hydrolysate in practical diets on the growth and survival of redclaw crayfish hatchlings Cherax quadricarinatus (von Martens, 1868). Aquaculture Research 44(6):966-973. doi: 10.1111/j.1365-2109.2012.03102.x

AsGARI L (2004). Broodstock nutrition of Australian red claw 
crayfish Cherax quadricarinatus (von Martens). Agriculture. Universiti Putra Malaysia.

BARKER PL AND GibSON R (1977). Observations on the feeding mechanism, structure of the gut, and digestive physiology of the European lobster Homarus gammarus (L.)(Decapoda: Nephropidae). Journal of Experimental Marine Biology and Ecology 26(3):297-324. doi: 10.1016/0022-0981(77)90089-2

BARKI A AND KARPLUS I (1999). Behavioural assay for receptivity in female Cherax quadricarinatus: does she show? Freshwater Crayfish 12:918-919.

BARKI A AND Karplus I (2000). Crowding female red claw crayfish, Cherax quadricarinatus, under small-tanks hatchery conditions: what is the limit? Aquaculture 181(3-4):235-240. doi: $10.1016 / \mathrm{S} 0044-8486(99) 00235-5$

Barki A, Karplus I, Manor R, Parnes S, Aflalo E and Sagi A (2006). Growth of redclaw crayfish (Cherax quadricarinatus) in a three-dimensional compartments system: Does a neighbor matter? Aquaculture 252(2-4):348-355. doi: 10.1016/j. aquaculture.2005.07.012

BARKI A, LEVI T, SHREM A AND KARPLUS I (1997). Ration and spatial distribution of feed affect survival, growth, and competition in juvenile red-claw crayfish, Cherax quadricarinatus, reared in the laboratory. Aquaculture 148(1997):169-177. doi: 10.1016/ S0044-8486(96)01418-4

Biтомsкy J (2008). Scoping Report Redclaw Industry Development. Kleinhardt Business Consultants, Cairns.

Brown PB, Wetzel II JE, Spacie A and Konopka A (1992). Evaluation of naturally-occurring organisms as food for juvenile crayfish Procambarus clarkii. Journal of the World Aquaculture Society 23:211-216. doi: 10.1111/j.17497345.1992.tb00771.x

Bugnot AB AND LóPEz GRECo LS (2009). Structural alterations in the male reproductive system of the freshwater crayfish, Cherax quadricarinatus (Decapoda, Parastacidae). Journal of Invertebrate Pathology 102(2):160-166. doi: 10.1016/j. jip.2009.08.004

Calvo NS, Stumpf L, Pietrokovsky S and López Greco LS (2011). Early and late effects of feed restriction on survival, growth and hepatopancreas structure in juveniles of the red claw crayfish Cherax quadricarinatus. Aquaculture 319(34):355-362. doi: 10.1016/j.aquaculture.2011.06.033

Calvo NS, Stumpf L, Sacristán HJ and López Greco LS (2013). Energetic reserves and digestive enzyme activities in juveniles of the red claw crayfish Cherax quadricarinatus nearby the point-of-no-return. Aquaculture 416-417:85-91. doi: $10.1016 /$ j.aquaculture.2013.08.017

CAMPAÑA T (2001). Digestibility of vegetal and animal ingredients and diets for juvenile and pre-adult redclaw Cherax quadricarinatus. CIBNOR, SC La Paz, BCS, Mexico.

Campaña-Torres A, Martínez-Córdova LR, VillarrealColmenares H and Civera-Cerecedo R (2006). Carbohydrate and lipid digestibility of animal and vegetal ingredients and diets for juvenile Australian redclaw crayfish, Cherax quadricarinatus. Aquaculture Nutrition 12(2):103-
109. doi: $10.1111 / \mathrm{j} .1365-2095.2006 .00388 . \mathrm{x}$

CAMpaña-Torres A, Martínez-Córdova LR, VillarrealColmenares H and Civera-Cerecedo R (2005). In vivo dry matter and protein digestibility of three plant-derived and four animal-derived feedstuffs and diets for juvenile Australian redclaw, Cherax quadricarinatus. Aquaculture 250(3-4):748754. doi: $10.1016 / \mathrm{j}$.aquaculture.2005.02.058

CAMPaÑa-Torres A, MartínEZ-CóRdova LR, VillarreaLColmenares H and Civera-Cerecedo R (2008). Carbohydrate and lipid digestibility of animal and vegetal ingredients and diets for the pre-adult redclaw crayfish, Cherax quadricarinatus (von Martens). Aquaculture Research 39(10):1115-1121. doi: 10.1111/j.1365-2109.2008.01980.x

Celada JD, Carral JM, Gaudioso VR, Temiño C and FERNÁNDEZ R (1989). Response of juvenile freshwater crayfish (Pacifastacus leniusculus Dana) to several fresh and artificially compounded diets. Aquaculture 76(1-2):67-78. doi: $10.1016 / 0044-8486(89) 90252-4$

Cortés-Jacinto E, CAmpa-Córdova ÁI, Ascencio F, VillarrealColmenares H and Holguín-Peña RJ (2009). The effect of protein and energy levels in diet on the antioxidant activity of juvenile redclaw Cherax quadricarinatus (von Martens, 1868). Hidrobiológica 19(2):77-83. doi: 10.1111/j.13652095.2005.00353.x

Cortés-Jacinto E， Villarreal-Colmenares H, CiveraCerecedo R and Cruz-Suárez L (2004a). Studies on the nutrition of the freshwater crayfish Cherax quadricarinatus (von Martens): effect of the dietary protein level on growth of juveniles and preadults. Freshwater Crayfish 14:70-80.

Cortés-Jacinto E， Villarreal-Colmenares H, CruzSuárez LE, Civera-Cerecedo R, Nolasco-Soria H and HernandeZ-Llamas A (2005). Effect of different dietary protein and lipid levels on growth and survival of juvenile Australian redclaw crayfish, Cherax quadricarinatus (von Martens). Aquaculture Nutrition 11(4):283-291. doi: 10.1111/j.1365-2095.2005.00353.x

Cortés-Jacinto E， Villarreal-Colmenares H, CiveraCERECEDo R and Martínez-CóRdova R (2003). Effect of dietary protein level on growth and survival of juvenile freshwater crayfish Cherax quadricarinatus (Decapoda: Parastacidae). Aquaculture Nutrition 9(4):207-213. doi: 10.1046/j.1365-2095.2003.00241.x

Cortés-Jacinto E, Villarreal-Colmenares H, CiveraCerecedo R and Naranjo-Páramo J (2004b). Effect of dietary protein level on the growth and survival of pre-adult freshwater crayfish Cherax quadricarinatus (von Martens) in monosex culture. Aquaculture Research 35(1):71-79. doi: 10.1111/j.1365-2109.2004.00988.x

CuRTis MC and Jones CM (1995). Observations on monosex culture of redclaw crayfish Cherax quadricarinatus von Martens (Decapoda: Parastacidae) in earthen ponds. Journal of the World Aquaculture Society 26(2):154-159. doi: 10.1111/j.1749-7345.1995.tb00238.x

D'Abramo LR, Wright JS, Wright KH, Bordner CE AND Conklin DE (1985). Sterol requirement of cultured juvenile 
crayfish, Pacifastacus leniusculus. Aquaculture 49(3):245255. doi: $10.1016 / 0044-8486(85) 90083-3$

D’Abramo LR and Robinson EH (1989). Nutrition of crayfish. Reviews in Aquatic Sciences 1(4):711-728.

Dall W, Hill BJ, Rothlisberg PC and Sharples DJ (1991). The biology of the Penaeidae. Advances in Marine Biology 27:489. doi: 10.1016/S0065-2881(08)60166-2

Dammannagoda LK, Pavasovic A, Hurwood DA and Mather PB (2015). Effects of soluble dietary cellulose on specific growth rate, survival and digestive enzyme activities in three freshwater crayfish (Cherax) species. Aquaculture Research 46(3):626-636. doi: 10.1111/are.12209

Daniels WH, D'Abramo LR, Fondren MW and Durant MD (1995). Effects of stocking density and feed on pond production characteristics and revenue of harvested freshwater prawns Macrobrachium rosenbergii stocked as size-graded juveniles. Journal of the World Aquaculture Society 26(1):38-47. doi: 10.1111/j.1749-7345.1995.tb00207.x

DE Bock MS AND LóPEz Greco LS (2009). Sex reversal and growth performance in juvenile females of the freshwater crayfish Cherax quadricarinatus (Parastacidae): effect of increasing temperature and androgenic gland extract in the diet. Aquaculture International 18(2):231-243. doi: 10.1007/ s10499-008-9239-x

Doupé RG, Morgan DL, Gill HS and Rowland AJ (2004). Introduction of redclaw crayfish Cherax quadricarinatus (von Martens) to Lake Kununurra, Ord River, Western Australia: prospects for a 'yabby' in the Kimberley. Journal of the Royal Society of Western Australia 87(4):187-191.

Duarte CM, Agusti S and Peters H (1987). An upper limit to the abundance of aquatic organisms. Oecologia 74(2):272-276. doi: $10.1007 / \mathrm{BF} 00379370$

FAO (2016). The State of World Fisheries and Aquaculture 2016. Contributing to food security and nutrition for all. Pp.200. FAO, Rome.

FAO (2017). Cherax quadricarinatus (von Martens, 1868). Cultured species information program. [online] FFaAD, FAO, Rome.

FIGUEIREDO MSRB AND ANDERSONAJ (2003). Ontogenetic changes in digestive proteases and carbohydrases from the Australian freshwater crayfish, redclaw Cherax quadricarinatus (Crustacea, Decapoda, Parastacidae). Aquaculture Research 34(13):1235-1239. doi: 10.1046/j.1365-2109.2003.00929.x

Figueiredo MSRB, Kricker JA AND ANDERSON AJ (2001). Digestive Enzyme Activities in the Alimentary Tract of Redclaw Crayfish, Cherax quadricarinatus (Decapoda: Parastacidae). Journal of Crustacean Biology 21(2):334-344. doi: $10.1163 / 20021975-99990133$

FLeTCHer A AND Warburton K (1997). Consumption of fresh and decomposed duckweed Spirodela sp. by redclaw crayfish, Cherax quadricarinatus (von Martens). Aquaculture Research 28(5):379-382. doi:10.1046/j.1365-2109.1997.t01-1-00808.x

García-Guerrero M, Hernández-Sandoval P, Orduña-Rojas J AND CORTÉS-JACINTO E (2013). Effect of temperature on weight increase, survival, and thermal preference of juvenile redclaw crayfish Cherax quadricarinatus. Hidrobiológica 23(1):73-81.

García-Guerrero M, Racotta IS, RodríGuez-Jaramillo C, VILLARREAL H AND CORTÉS-JACINTO E (2003a). Energy storage during the transition from endogenous to exogenous feeding in Australian redclaw crayfish Cherax quadricarinatus (Von Martens, 1898). Invertebrate Reproduction and Development 44(2-3):101-106. doi: 10.1080/07924259.2003.9652560

García-Guerrero M, Villarreal H and Racotta IS (2003b). Effect of temperature on lipids, proteins, and carbohydrates levels during development from egg extrusion to juvenile stage of Cherax quadricarinatus (Decapoda: Parastacidae). Comparative Biochemistry and Physiology Part A: Molecular and Integrative Physiology 135(1):147-154. doi: 10.1016/ s1095-6433(02)00354-9

García-Ulloa GM, López-Chavarín HM, RodríGuezGonZÁlez H and Villarreal-Colmenares H (2003). Growth of redclaw crayfish Cherax quadricarinatus (von Martens 1868) (Decapoda: Parastacidae) juveniles fed isoproteic diets with partial or total substitution of fish meal by soya bean meal: preliminary study. Aquaculture Nutrition 9(1):25-31. doi: 10.1046/j.1365-2095.2003.00224.x

GaRZA DE YTA A (2009). Hatchery, nursery, nutrition and stock evaluation of redclaw crayfish Cherax quadricarinatus. Pp. 135. Auburn University.

Garza de Yta A, Davis DA, Rouse DB, Saoud IP and Ghanawi J (2011). Effects of stargrass hay supplementation on growth and survival of juvenile redclaw crayfish Cherax quadricarinatus. North American Journal of Aquaculture 73(4):484-488. doi: 10.1080/15222055.2011.635244

Geddes MC, Smallridge M and Clarke S (1993). The effect of stocking density, food type and shelters on survival and growth of the Australian freshwater crayfish, Cherax destructor, in experimental ponds. Freshwater Crayfish 9:57-69.

Ghanawi J And SAOUd IP (2012). Molting, reproductive biology, and hatchery management of redclaw crayfish Cherax quadricarinatus (von Martens 1868). Aquaculture 358359:183-195. doi: 10.1016/j.aquaculture.2012.06.019

Guillaume J (1997). Protein and amino acids. Pp. 26-50, In: D'Abramo LR, Conklin DE and Akiyama DM (eds.). Crustacean Nutrition. Adavances in World Aquaculture. World Aquaculture Society, Baton Rouge, Louisiana, USA.

Guillaume J and Choubert G (2001). Digestive physiology and nutrient digestibility in fishes. Pp. 27-56, In: Guillaume J, Kaushik S, Bergot P and Metailler R, (eds.). Nutrition and Feeding of Fish and Crustaceans. Springer Praxis United Kingdom.

GutiÉRREZ M AND RoDRÍGuEZ E (2010). Effect of protein source on growth of early juvenile redclaw crayfish Cherax quadricarinatus (Decapoda, Parastacidae). Freshwater Crayfish 17:23-29.

Henriksson PJG, Guinée JB, Kleijn R and de Snoo GR (2012). Life cycle assessment of aquaculture systems - a review 
of methodologies. The International Journal of Life Cycle Assessment 17(3):304-313. doi: 10.1007/s11367-011-0369-4

Hernández PV, Olvera-Novoa MA AND Rouse DB (2004). Effect of dietary cholesterol on growth and survival of juvenile redclaw crayfish Cherax quadricarinatus under laboratory conditions. Aquaculture 236(1-4):405-411. doi: 10.1016/j. aquaculture.2003.12.005

Hernández-Vergara MP, Rouse DB, Olvera-Novoa MA And DAvis DA (2003). Effects of dietary lipid level and source on growth and proximate composition of juvenile redclaw (Cherax quadricarinatus) reared under semi-intensive culture conditions. Aquaculture 223(1-4):107-115. doi: 10.1016/ S0044-8486(03)00135-2

Higley LG, Pedigo LP And Ostlie KR (1986). DEGDAY: a program for calculating degree-days, and assumptions behind the degree-day approach. Environmental Entomology 15(5):999-1016. doi: 10.1093/ee/15.5.999

JoAquí P AND Montes C (2001). Bioenergetics of juveniles of red swamp crayfish (Procambarus clarkii). Comparative Biochemistry and Physiology Part A: Molecular and Integrative Physiology 130(1):29-38. doi: 10.1016/S10956433(01)00358-0

Jones CM (1989). The Biology and Aquaculture Potential of Cherax quadricarinatus. Final Report for Project "The Assessment of Cherax quadricarinatus as a Candidate for Aquaculture. Reserve Bank of Australia, Rural Credits Development Fund, Project QDPI/8860. Pp. 131. Department of Primary Industries, Queensland, Walkamin, Australia.

Jones CM (1990a). Biology and Aquaculture Potential of the Tropical Australian Freshwater Crayfish (Cherax quadricarinatus). Pp. 19. Abstracts, Eighth International Symposium of the International Association of Astacology, Baton Rouge, Louisiana, USA. April 22-26, 1990.

Jones CM (1990b). The Biology and Aquaculture Potential of the Tropical Freshwater Crayfish, Cherax quadricarinatus. QI90028. Department of Primary Industries, Queensland, Brisbane, Australia.

Jones CM (1995a). Evaluation of six diets fed to redclaw, Cherax quadricarinatus (von Martens), held in pond enclosures. Freshwater Crayfish 10:469-479.

Jones CM(1995b). Production of juvenile redclaw crayfish, Cherax quadricarinatus (von Martens)(Decapoda, Parastacidae) I. Development of hatchery and nursery procedures. Aquaculture 138(1995):221-238. doi: 10.1016/0044-8486(95)00068-2

JoNes CM(1995c). Production of juvenile redclaw crayfish, Cherax quadricarinatus (von Martens)(Decapoda, Parastacidae) II. Juvenile nutrition and habitat. Aquaculture 138(1995):239245. doi: 10.1016/0044-8486(95)00069-0

Jones CM(1995d). Production of juvenile redclaw crayfish, Cherax quadricarinatus (von Martens)(Decapoda, Parastacidae) III. Managed pond production trials. Aquaculture 138(1995):247255. doi: 10.1016/0044-8486(95)00067-4
Jones CM (1995e). Salinity tolerance of the tropical freshwater crayfish, Cherax quadricarinatus (von Martens)(Decapoda, Parastacidae). Freshwater Crayfish 8:399-409.

Jones CM And Curtis MC (1994). Redclaw Farming. Pp. 69. Redclaw Farming Workshops, Feb.12-17, 1994, Walkamin, Rockhampton, Nambour. Queensland Department of Primary Industries.

Jones CM, McPhee CP And Ruscoe IM (2000). A review of genetic improvement in growth rate in redclaw crayfish Cherax quadricarinatus (von Martens) (Decapoda: Parastacidae). Aquaculture Research 31(1):61-67. doi: 10.1046/j.13652109.2000.00430.x

Jones CM AND Ruscoe IM (1996). Evaluation of six diets fed to redclaw, Cherax quadricarinatus (von Martens), (Decapoda: Parastacidae), under laboratory conditions. Pp. 19-30, In: Production Technology for Redclaw Crayfish (Cherax quadricarinatus). Final Report, Project 92/119, Fisheries Research and Development Corporation. Department of Primary Industries, Queensland, Walkamin.

Jones CM AND Ruscoe IM (2000). Assessment of stocking size and density in the production of redclaw crayfish, Cherax quadricarinatus (von Martens) (Decapoda: Parastacidae), cultured under earthen pond conditions. Aquaculture 189(12):63-71. doi: 10.1016/S0044-8486(00)00359-8

JoNES CM AND RusCOE IM (2001). Assessment of five shelter types in the production of redclaw crayfish Cherax quadricarinatus (Decapoda: Parastacidae) under earthen pond conditions. Journal of the World Aquaculture Society 32(1):41-52. doi: 10.1111/j.1749-7345.2001.tb00920.x

Jones CM AND RusCoE IM (2002). Biological and aquaculture characteristics of five stocks of redclaw, Cherax quadricarinatus (von Martens) (Decapoda: Parastacidae) from northern Queensland, Australia. Freshwater Crayfish 13:115-135.

Jones CM AND VALVERde C (2020). Development of mass production hatchery technology for the redclaw crayfish, Cherax quadricarinatus. Freshwater Crayfish 25(1):1-6. doi: 10.5869/fc.2020.v25-1.001

KARPLUS I AND BARKI A (2004). Social control of growth in the redclaw crayfish, Cherax quadricarinatus: testing the sensory modalities involved. Aquaculture 242(1-4):321-333. doi: 10.1016/j.aquaculture.2004.08.041

Karplus I, Barki A, Levi T, Hulata G and Harpaz S (1995). Effect of kinship and shelters on growth and survival of juvenile Australian redclaw crayfish (Cherax quadricarinatus). Freshwater Crayfish 10:494-505.

Karplus I, Gideon H AND BARKI A (2003). Shifting the natural spring-summer breeding season of the Australian freshwater crayfish Cherax quadricarinatus into the winter by environmental manipulations. Aquaculture 220(1-4):277286. doi: $10.1016 / \mathrm{s} 0044-8486(02) 00225-9$

KING CR (1994). Growth and survival of red claw crayfish hatchlings (Cherax quadricarinatus von Martens) in relation to temperature, with comments on the relative suitability of 
Cherax quadricarinatus and Cherax destructor for culture in Queensland. Aquaculture 122:75-80. doi: 10.1016/00448486(94)90335-2

Kondos A (1990). Supplementary feed essential for crayfish. Australian Fisheries 49(11):28-30.

Lavalli KL and FACtor JR (1992). Functional morphology of the mouthparts of juvenile lobsters, Homarus americanus (Decapoda: Nephropidae), and comparison with the larval stages. Journal of Crustacean Biology 12(3):467-510. doi: $10.2307 / 1549041$

Lavalli KL and Factor JR (1995). The feeding appendages. Pp. 349-393, In: Factor JR (ed.). Biology of the Lobster Homarus americanus. Academic press, San Diego, California, USA.

Lawrence C and Jones C (2002). Chapter 17. Cherax. Pp. 635670, In: Holdich DM, (ed.). Biology of Freshwater Crayfish. Blackwell Science Ltd, Oxford, UK.

Levi T, Barki A, Hulata G and Karplus I (1999). Motheroffspring relationships in the red-claw crayfish Cherax quadricarinatus. Journal of Crustacean Biology 19(3):477484. doi: $10.2307 / 1549256$

Li JY, Guo ZL, Gan XH, WANG DL, Zhang MF and Zhao YL (2011). Effect of different dietary lipid sources on growth and gonad maturation of pre-adult female Cherax quadricarinatus (von Martens). Aquaculture Nutrition 17(4):e853-e860. doi: 10.1111/j.1365-2095.2011.00852.x

LODGE D AND HiLL A (1994). Factors governing species composition, population size and productivity of cool-water crayfishes. Nordic Journal of Freshwater Research (Sweden) 69:111-136.

López-López S, Nolasco H, Villarreal-Colmenares H and Civera-Cerecedo R (2005). Digestive enzyme response to supplemental ingredients in practical diets for juvenile freshwater crayfish Cherax quadricarinatus. Aquaculture Nutrition 11(2):79-85. doi: 10.1111/j.13652095.2004.00305.x

Lovett DL and Felder DL (1990). Ontogenetic change in digestive enzyme activity of larval and postlarval white shrimp Penaeus setiferus (Crustacea, Decapoda, Penaeidae). The Biological Bulletin 178(2):144-159. doi: 10.2307/1541973

Loya-Javellana GN and Fielder DR (1997). Developmental trends in the mouthparts during growth from juvenile to adult of the tropical freshwater crayfish, Cherax quadricarinatus von Martens, 1868 (Decapoda: Parastacidae). Invertebrate Reproduction and Development 32(2):167-175. doi: 10.1080/07924259.1997.9672619

LoYa-JaVELlana GN, Fielder DR AND Thorne MJ (1993). Food choice by free-living stages of the tropical freshwater crayfish, Cherax quadricarinatus (Parastacidae: Decapoda). Aquaculture 118(3):299-308. doi: 10.1016/0044-8486(93)90464-A

Manor R, Aflalo ED, Segall C, Weil S, Azulay D, Ventura $T$ AND SAGI A (2004). Androgenic gland implantation promotes growth and inhibits vitellogenesis in Cherax quadricarinatus females held in individual compartments.
Invertebrate Reproduction and Development 45(2):151-159. doi: $10.1080 / 07924259.2004 .9652584$

Manor R, Segev R, Leibovitz MP, Aflalo ED and Sagi A (2002). Intensification of redclaw crayfish Cherax quadricarinatus culture: II. Growout in a separate cell system. Aquacultural Engineering 26(4):263-276. doi: 10.1016/ S0144-8609(02)00035-3

MAson J (1975). Crayfish production in a small woodland stream. Freshwater Crayfish 2:449-479.

Masser M and Rouse D (1993). Production of Australian red claw crayfish. Alabama Cooperative Extension Service, USA.

Masser MP and Rouse BD (1997). Australian Red Claw Crayfish. SRAC Publication No.244. The Alabama Cooperative Extension Service, USA.

McClain WR, Neill WH and Gatlin DM(1992). Nutrient profiles of green and decomposed rice-forages and their utilization by juvenile crayfish (Procambarus clarkii). Aquaculture 101(34):251-265. doi: 10.1016/0044-8486(92)90029-K

McPhee CP, Jones CM And Shanks SA (2004). Selection for increased weight at nine months in Redclaw crayfish (Cherax quadricarinatus). Aquaculture 237(1-4):131-140. doi: 10.1016/j.aquaculture.2004.05.008

Meade ME and Watts SA (1995). Weight gain and survival of juvenile Australian crayfish Cherax quadricarinatus fed formulated feeds. Journal of the World Aquaculture Society 26(4):469-474. doi: 10.1111/j.1749-7345.1995.tb00845.x

Medley PB, Nelson RG, Hatch LU, Rouse DB and Pinto GF (1994). Economic feasibility and risk analysis of Australian red claw crayfish Cherax quadricarinatus aquaculture in the southeastern United States. Journal of the World Aquaculture Society 25(1):135-146. doi: 10.1111/j.1749-7345.1994. tb00813.x

Metts LS, Thompson KR, Xiong Y, Kong B, Webster CD And BRADY Y (2007). Use of alfalfa hay, compared to feeding practical diets containing two protein levels, on growth, survival, body composition, and processing traits of Australian red claw crayfish, Cherax quadricarinatus, grown in ponds. Journal of the World Aquaculture Society 38(2):218-230. doi: 10.1111/j.1749-7345.2007.00091.x

Mitchell BD and Collins R (1989). Development of field-scale intensive culture techniques for the commercial production of the yabbie (Cherax destructor/albidus). Centre for Aquatic Science, Warrnambool Institute of Advanced Education, Warrnambool, Victoria.

Момот WT (1995). Redefining the role of crayfish in aquatic ecosystems. Reviews in Fisheries Science 3(1):33-63. doi: 10.1080/10641269509388566

Morrissy NM, BIRD C AND CASSELls G (1995). Density-dependent growth of cultured marron, Cherax tenuimaus (Smith 1912). Freshwater Crayfish 10:560-568.

Msangi S, Kobayashi M, Batka M, Vannuccini S, Dey M and ANDERson J (2013). Fish to 2030: prospects for fisheries and aquaculture. World Bank Report (83177-GLB). 
Muzinic LA, Thompson KR, Morris A, Webster CD, Rouse DB and Manomaitis L (2004). Partial and total replacement of fish meal with soybean meal and brewer's grains with yeast in practical diets for Australian red claw crayfish Cherax quadricarinatus. Aquaculture 230(1-4):359-376. doi: 10.1016/S0044-8486(03)00420-4

Naranjo-PÁramo J, Hernandez-Llamas A and Villarreal H (2004). Effect of stocking density on growth, survival and yield of juvenile redclaw crayfish Cherax quadricarinatus (Decapoda: Parastacidae) in gravel-lined commercial nursery ponds. Aquaculture 242(1-4):197-206. doi: 10.1016/j. aquaculture.2004.05.017

Nyström P (2002). Chapter 5. Ecology. Pp. 192-235, In: Biology of Freshwater Crayfish. Holdich DM, (ed.). Blackwell, London, UK.

O'Sullivan D, Fielder D and Jones C (2003). Chapter 20. Freshwater Crustaceans. Pp. 420-442, In: Aquaculture: Farming Aquatic Animals and Plants. Lucas JS and Southgate PC, (eds.). Blackwell Publishing, Oxford, England, UK.

PARnes S AND SAGi A (2002). Intensification of redclaw crayfish Cherax quadricarinatus culture: I. Hatchery and nursery system. Aquacultural Engineering 26(4):251-262. doi: 10.1016/S0144-8609(02)00034-1

PARVATHY K (1971). Glycogen storage in relation to the moult cycle in the two crustaceans Emerita asiatica and Ligia exotica. Marine Biology 10(1):82-86. doi: 10.1007/BF02026770

Pavasovic A, Anderson AJ, Mather PB and Richardson NA (2007a). Effect of a variety of animal, plant and single cellbased feed ingredients on diet digestibility and digestive enzyme activity in redclaw crayfish, Cherax quadricarinatus (von Martens 1868). Aquaculture 272(1-4):564-572. doi: 10.1016/j.aquaculture.2007.08.027

Pavasovic A, Anderson AJ, Mather PB and Richardson NA (2007b). Influence of dietary protein on digestive enzyme activity, growth and tail muscle composition in redclaw crayfish, Cherax quadricarinatus (von Martens). Aquaculture Research 38(6):644-652. doi: 10.1111/j.13652109.2007.01708.x

Pavasovic A, Richardson NA, Mather PB and Anderson AJ (2006). Influence of insoluble dietary cellulose on digestive enzyme activity, feed digestibility and survival in the red claw crayfish, Cherax quadricarinatus (von Martens). Aquaculture Research 37(1):25-32. doi: 10.1111/j.13652109.2005.01389.x

PILlaY TVR (1990). Aquaculture: principles and practices. Fishing News Books.

Pinto GF AND Rouse DB (1996). Growth and survival of the Australian red claw crayfish Cherax quadricarinatus at three densities in earthen ponds. Journal of the World Aquaculture Society 27(2):187-193. doi: 10.1111/j.1749-7345.1996. tb00268.x

Pirozzi I, Joyce M, Clay S, Owens L, Villacis Conrado D, Huv le H, Chau Nguyen M, Pichette A and Stright $T$ (2015). Boosting Redclaw Industry Productivity with
Improved Nutrition \& Feed Management. Final Report for RIRDC Project No. PRJ-008536. Pp. 123, In: Corporation AGRIRaD, (ed.) Australian Government, Canberra.

Priyambodo B, Jones C and Sammut J (2015). The effect of trap type and water depth on puerulus settlement in the spiny lobster aquaculture industry in Indonesia. Aquaculture 442:132-137. doi: $10.1016 / j$.aquaculture.2015.02.037

Priyambodo B, Jones CM and Sammut J (2017). Improved collector design for the capture of tropical spiny lobster, Panulirus homarus and P. ornatus (Decapoda: Palinuridae), pueruli in Lombok, Indonesia. Aquaculture 479:321-332. doi: 10.1016/ j.aquaculture.2017.05.033

QUEENSLAND GOVERNMENT (2007). Redclaw crayfish information package. Pp. 92. Queensland Government, Brisbane.

QueEnsland Government (2015). Ross Lobegeiger Report to Farmers. Aquaculture production summary for Queensland 2014 -15. Pp. 11. Queensland Government, Brisbane.

QueEnsland Government (2016). Ross Lobegeiger Report to Farmers. Aquaculture production summary for Queensland 2015 -16. Pp. 11. Queensland Government, Brisbane.

Queensland Government (2018). Ross Lobegeiger report to farmers. Aquaculture production summary for Queensland 2017-18. Pp. 8. Queensland Government, Brisbane.

Queensland Government (2020). Ross Lobegeiger report to farmers. Aquaculture production summary for Queensland 2018-19. Pp. 8. Queensland Government, Brisbane.

RANJAN R AND BAVITHA M (2015). Lupins - an alternative protein source for aquaculture diets. International Journal of Applied Research 1(3):04-08.

Rodgers LJ, Saoud PI and Rouse DB (2006). The effects of monosex culture and stocking density on survival, growth and yield of redclaw crayfish (Cherax quadricarinatus) in earthen ponds. Aquaculture 259(1):164-168. doi: 10.1016/j. aquaculture.2005.11.056

Rodríguez-Canto A, Arredondo-Figueroa JL, PoncePalafox JT AND Rouse DB (2002). Growth characteristics of the Australian redclaw crayfish, Cherax quadricarinatus, cultured in an indoor recirculating system. Journal of Applied Aquaculture 12(3):59-64. doi: 10.1300/J028v12n03_06

RodríGuez-González H, García-Ulloa M, HernándeZLlamas A and Villarreal H (2006). Effect of dietary protein level on spawning and egg quality of redclaw crayfish Cherax quadricarinatus. Aquaculture 257(1-4):412-419. doi: 10.1016/j.aquaculture.2006.01.020

Rodriguez-Gonzalez H, Villarreal H, Garcia-Ulloa M and HernandeZ-Llamas A (2009a). Evaluation of practical diets containing different protein levels on gonad development of female redclaw crayfish Cherax quadricarinatus. Aquaculture Nutrition 15(4):347-355. doi: 10.1111/j.13652095.2008.00599.x

Rodríguez-González H, Villarreal H, HernándeZLlamas A, García-Ulloa M, Vázquez-Boucard C and SERRANO-PINTO V (2011). Effect of dietary protein-to-energy ratio on reproduction in female redclaw crayfish Cherax 
quadricarinatus. Aquaculture Research 42(12):1840-1847. doi: $10.1111 / \mathrm{j} .1365-2109.2010 .02787 . \mathrm{x}$

RodrígueZ-González H, Villarreal H, García-Ulloa M and HERNÁNDEZ-Llamas A (2009b). Dietary lipid requirements for optimal egg quality of redclaw crayfish, Cherax quadricarinatus. Journal of the World Aquaculture Society 40(4):531-539. doi: 10.1111/j.1749-7345.2009.00267.x

ROMERo X (2002). Ups and downs of red claw crayfish farming in Ecuador. World Aquaculture 33(2):40-46.

Romero X AND Jimenez R (2002). Histopathological survey of diseases and pathogens present in redclaw crayfish, Cherax quadricarinatus (von Martens), cultured in Ecuador. Journal of Fish Diseases 25(11):653-667. doi: 10.1046/j.13652761.2002.00411.x

ROMERo XM (1998). After the bubble burst: redclaw farming in Ecuador. Crayfish News 20(3):7-8.

Rouse DB (1994). A new species for Ecuador? World Aquaculture 25(3):51.

Rouse DB AND YeH HS (1995). Factors influencing spawning of Cherax quadricarinatus in indoor hatcheries. Freshwater Crayfish 10:605-610.

Ruscoe IM, Jones CM, Jones PL And Caley P (2005). The effects of various binders and moisture content on pellet stability of research diets for freshwater crayfish. Aquaculture Nutrition 11(2):87-93. doi: 10.1111/j.1365-2095.2004.00324.x

Ruscoe IM, Jones PL AND Jones CM (2000). Effects of feeding moist and dry diets to redclaw crayfish, Cherax quadricarinatus, in tanks. Freshwater Crayfish 13:164-176.

Salame M (1995). Successful culture of red claw crawfish, Cherax quadricarinatus. Pp. 204. World Aquaculture Society.

Sammy N (1988). Breeding biology of Cherax quadricarinatus in the Northern Territory. Pp. 79-88, In: Proceedings of the First Australian Aquaculture Conference, Perth, 23-27 October, 1988. Evans LH and O'Sullivan D (eds.). Curtin University of Technology, Western Australia.

Sánchez-Paz A, García-Carreño F, Muhlia-Almazán A, Peregrino-Uriarte AB, Hernández-López J and YePiz-Plascencia G (2006). Usage of energy reserves in crustaceans during starvation: status and future directions. Insect Biochemistry and Molecular Biology 36(4):241-249. doi: $10.1016 / \mathrm{j} . \mathrm{ibmb} .2006 .01 .002$

Saoud IP, Garza de Yta A and Ghanawi J (2012). A review of nutritional biology and dietary requirements of redclaw crayfish Cherax quadricarinatus (von Martens 1868). Aquaculture Nutrition 18(4):349-368. doi: 10.1111/j.13652095.2011.00925.x

Saoud IP, Ghanawi J, Thompson KR and Webster CD (2013). A review of the culture and diseases of redclaw crayfish Cherax quadricarinatus (von Martens 1868). Journal of the World Aquaculture Society 44(1):1-29. doi: 10.1111/jwas.12011

SAOUd IP, Rodgers LJ, Davis DA and Rouse DB (2008). Replacement of fish meal with poultry by-product meal in practical diets for redclaw crayfish (Cherax quadricarinatus).
Aquaculture Nutrition 14(2):139-142. doi: 10.1111/j.13652095.2007.00513.x

Savage J and Hobsbawn P (2015). Australian fisheries and aquaculture statistics 2014. FRDC project 2014/245. Australian Government, Canberra.

SEDGWICK RW (1979). Influence of dietary protein and energy on growth, food consumption and food conversion efficiency in Penaeus merguiensis de Man. Aquaculture 16(1):7-30. doi: 10.1016/0044-8486(79)90168-6

Smith TIJ AND SANDIFER PA (1979). Observations on the behavior of the Malaysian prawn, Macrobrachium rosenbergii (de Man), to artificial habitats. Marine and Freshwater Behaviour and Physiology 6(2):131-146. doi: 10.1080/10236247909378560

Stevenson J, Jerry D and Owens L (2013). Redclaw Selective Breeding Project. RIRDC Publication No. 13/007 RIRDC Project No. PRJ-000327 Final Report. Pp. 47. Rural Industries Research and Development Corporation, Canberra.

Stumpf L, Tropea C and López Greco LS (2014). Recovery growth of Cherax quadricarinatus juveniles fed on two highprotein diets: Effect of daily feeding following a cyclic feeding period on growth, biochemical composition and activity of digestive enzymes. Aquaculture 433:404-410. doi: 10.1016/j. aquaculture.2014.06.037

TCHERKASHINA NY (1977). Survival, growth and feeding dynamics of juvenile crayfish (Astacus leptodactylus cubanicus) in ponds and the River Don. Freshwater Crayfish 3:95-100.

Thompson KR, Bailey TJ, Metts LS, Brady YJ and Webster CD (2010). Growth response and fatty acid composition of juvenile red claw crayfish (Cherax quadricarinatus) fed different sources of dietary lipid. Aquaculture Nutrition 16(6):604-615. doi: 10.1111/j.1365-2095.2009.00697.x

Thompson KR, Metts LS, Muzinic LA, Dasgupta S And WeBster CD (2006). Effects of feeding practical diets containing different protein levels, with or without fish meal, on growth, survival, body composition and processing traits of male and female Australian red claw crayfish (Cherax quadricarinatus) grown in ponds. Aquaculture Nutrition 12(3):227-238. doi: 10.1111/j.1365-2095.2006.00407.x

Thompson KR, Muzinic LA, Christian TD, Webster CD, Manomaitis L and Rouse DB (2003a). Effect on growth, survival, and fatty acid composition of Australian red claw crayfish Cherax quadricarinatus fed practical diets with and without supplemental lecithin and/or cholesterol. Journal of the World Aquaculture Society 34(1):1-10. doi: 10.1111/ j.1749-7345.2003.tb00033.x

Thompson KR, Muzinic LA, Christian TD, Webster CD, Manomaitis L and Rouse DB (2003b). Lecithin requirements of juvenile Australian red claw crayfish Cherax quadricarinatus. Aquaculture Nutrition 9(4):223-230. doi: 10.1046/j.1365-2095.2003.00246.x

Thompson KR, Muzinic LA, Engler LS, Morton S-R and WeBster CD (2004). Effects of feeding practical diets containing various protein levels on growth, survival, body composition, and processing traits of Australian red claw 
crayfish (Cherax quadricarinatus) and on pond water quality. Aquaculture Research 35(7):659-668. doi: 10.1111/j.13652109.2004.01063.x

ThOMPson KR, Muzinic LA, Engler LS AND Webster CD (2005). Evaluation of practical diets containing different protein levels, with or without fish meal, for juvenile Australian red claw crayfish (Cherax quadricarinatus). Aquaculture 244(1-4):241-249. doi: 10.1016/j.aquaculture.2004.11.018

Tidwell JH, Coyle S, Webel C and Evans J (1999). Effects and interactions of stocking density and added substrate on production and population structure of freshwater prawns Macrobrachium rosenbergii. Journal of the World Aquaculture Society 30(2):174-179. doi: 10.1111/j.1749-7345.1999. tb00864.x

Vazquez FJ, Chaulet A, Bugnot A and López-Greco LS (2004). Effect of temperature on sexual differentiation in juveniles of the freshwater crayfish, Cherax quadricarinatus (Astacida, Parastacidae). Pp. 255-259. Proceedings of the III Gongreso Iberoamerican Virtual de Acuiculura.

Viau VE, Ostera JM, Tolivia A, Ballester ElC, Abreu PC AND RoDríguez EM (2012). Contribution of biofilm to water quality, survival and growth of juveniles of the freshwater crayfish Cherax quadricarinatus (Decapoda, Parastacidae). Aquaculture 324-325:70-78. doi: 10.1016/j. aquaculture.2011.10.009

VIAU VE AND RODRÍGUEZ EM (2009). Substrate selection and effect of different substrates on survival and growth of juveniles of the freshwater crayfish Cherax quadricarinatus (von Martens 1868) (Decapoda, Parastacidae). Aquaculture International 18(5):717-724. doi: 10.1007/s10499-009-9292-0

Volpe MG, Santagata G, Coccia E, Di Stasio M, Malinconico M AND PAOLUCCI M (2015). Pectin-based pellets for crayfish aquaculture: structural and functional characteristics and effects on Redclaw Cherax quadricarinatus performances. Aquaculture Nutrition 21(6):814-823. doi: 10.1111/anu.12204

Webster CD, Thompson KR, Muzinic LA, Yancey DH, Dasgupta S, Xiong YL, Rouse DB and Manomaitis L (2004). A preliminary assessment of growth, survival, yield, and economic return of Australian red claw crayfish, Cherax quadricarinatus, stocked at three densities in earthen ponds in a cool, temperate climate. Journal of Applied Aquaculture 15(3-4):37-50. doi: 10.1300/J028v15n03_03

Wouters R, Lavens P, Nieto J and Sorgeloos P (2001). Penaeid shrimp broodstock nutrition: an updated review on research and development. Aquaculture 202(1-2):1-21. doi: 10.1016/ S0044-8486(01)00570-1

Xue XM, Anderson AJ, Richardson NA, Xue GP And MATHER PB (1999). Characterisation of cellulase activity in the digestive system of the redclaw crayfish (Cherax quadricarinatus). Aquaculture 180(1999):373-386. doi: 10.1016/S0044-8486(99)00213-6

YEH HS AND Rouse DB (1994). Indoor spawning and egg development of the red claw crayfish Cherax quadricarinatus. Journal of the World Aquaculture Society 25(2):297-302. doi: 10.1111/j.1749-7345.1994.tb00194.x
Zenteno-Savín T, Cortes-Jacinto E, VázQuez-Medina JP And Villarreal-Colmenares H (2008). Oxidative damage in tissues of juvenile crayfish (Cherax quadricarinatus von Martens, 1868) fed with different levels of proteins and lipid. Hidrobiológica 18(2):147-154. doi: 10.1111/j.13652095.2005.00353.X

Zhao Y, Meng F, Chen L, Gu Z, Xu G and Liu Q (2000). Effects of different gradient temperatures on embryonic development of the Cherax quadricarinatus (Crustacea, Decapoda). Journal of Lake Sciences 12(1):59-62. doi: 10.18307/2000.0109

Zhu H, Jiang Q, Wang Q, Yang J, Dong S and Yang J (2013). Effect of dietary carbohydrate-to-lipid ratios on growth performance, body composition, hepatic enzyme activities, and digestive enzyme activities of juvenile Australian redclaw crayfish, Cherax quadricarinatus (von Martens). Journal of the World Aquaculture Society 44(2):173-186. doi: 10.1111/ jwas. 12024 